

\section{BUKU AJAR \\ METODOLOGI STUDI ISLAM \\ DAN KAJIAN ISLAM KONTEMPORER \\ PERSPEKTIF INSIDER /OUTSIDER}

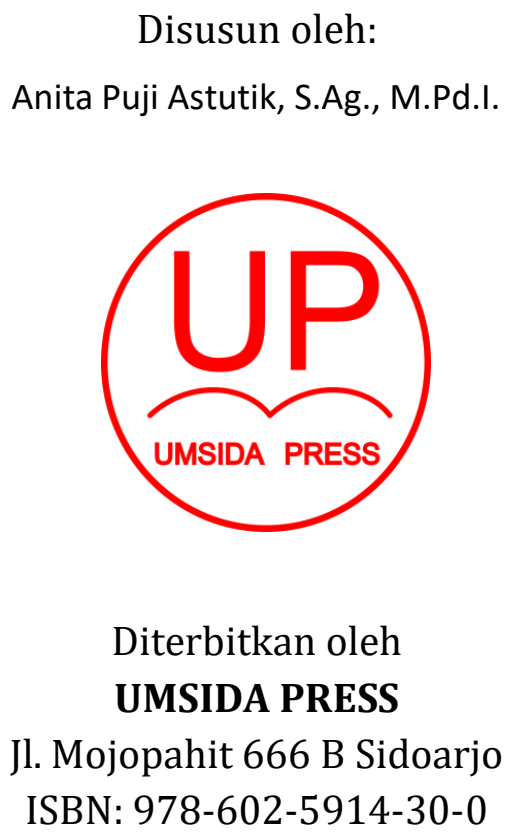

Copyright(C)2018.

Authors

All rights reserved 


\section{BUKU AJAR \\ METODOLOGI STUDI ISLAM \\ DAN KAJIAN ISLAM KONTEMPORER PERSPEKTIF INSIDER \\ /OUTSIDER \\ Penulis : \\ Anita Puji Astutik, S.Ag., M.Pd.I.}

ISBN : 978-602-5914-30-0

\section{Editor :}

Septi Budi Sartika, M.Pd

M. Tanzil Multazam, S.H., M.Kn.

\section{Copy Editor :}

Fika Megawati, S.Pd., M.Pd.

Design Sampul dan Tata Letak :

Mochamad Nashrullah, S.Pd

\section{Penerbit :}

UMSIDA Press

\section{Redaksi :}

Universitas Muhammadiyah Sidoarjo

Jl. Mojopahit No 666B

Sidoarjo, Jawa TImur

Cetakan pertama, Agustus 2018

(C) Hak cipta dilindungi undang-undang

Dilarang memperbanyak karya tulis ini dengan suatu apapun tanpa ijin tertulis dari penerbit. 


\section{IDENTITAS BUKU}

Buku Metodologi Studi Islam dan Dunia Islam Kontemporer adalah bidang kajian Islam yang dapat dijadikan rujukan terhadap ketimpangan antara misi ideal Islam dan realitas keberagamaan umat dewasa ini, yang muncul sebab tidak dipahaminya Islam dengan sebagaimana mestinya. Selama ini umat Islam abai terhadap dimensi sosial ajaran Islam ketika mereka mencoba memahaminya. Islam dipahami secara parsial sebab belum adanya metodologi pemahaman yang komprehensif. Memang telah ada metode-metode tradisional yang mapan dan operasional yang digolongkan Mukti Ali menjadi naqli, aqli, dan kasyaf, tapi sayangnya selama ini ketiga metode tersebut berjalan sendirisendiri.

Berangkat dari kegelisahan inilah buku ini ditulis. Didalamnya menawarkan kerangka metodologis untuk memahami dan mengkaji Islam agar hasil kajiannya bisa bernilai operasional dan menggerakan peradaban ke arah yang lebih baik. Gambaran dunia Islam kontemporer juga akan dijelaskan dalam buku ini sebagai objek kajian terhadap tantangan atas masa depan dunia Islam. 


\section{KATA PENGANTAR}

Syukur Alhamdulillah kami haturkan kehadirat Allah SWT yang telah memberi rahmat dan karuniaNya, sehingga penulis dapat menyelesaikan buku ajar "Metodologi Studi Islam dan Dunia Islam Kontemporer" yang tentunya diharapkan dapat memberikan kontribusi positif bagi pembaca dan pemerhati kajian Islam khususnya bagi para mahasiswa, guru maupun peminat kajian Islam baik insider maupun Outsider.

Secara keseluruhan buku ini memuat 5 bab yang terdiri atas. Bab 1 membahas pengantar Metodologi Islam yang meliputi pengertian metodologi, arti dan ruang lingkup Studi Islam, Urgensi, signifikansi dan sejarah pertumbuhan studi Islam. Bab 2 membahas Islam dan IImu pengetahuan, Epistemologi Islam dipaparkan dengan jelas dalam bab 3. Sedangkan Bab 4 secara rinci menjelaskan berbagai pendekatan dalam studi Islam yang menjadi inti pembahasan dari buku ini. Untuk memperluas khazanah keilmuan, di akhir bab buku ini memaparkan tentang Kajian Islam Kontemporer Perspektif Insider/Outsider.

Akhir kata penulis menyampaikan ucapan terima kasih atas motivasi dan bantuan yang diberikan. Mudah-mudahan karya sederhana ini bermanfaat dan dicatat sebagai amal kebajikan di sisiNya. Amin.

Sidoarjo, 19 Januari 2018

Penulis

Anita Puji Astutik, S.Ag., M.Pd.I. 


\section{DAFTAR ISI}

Cover

Identitas Buku

Kata Pengantar

Daftar isi

Bab I : Pengantar Metodologi Studi Islam
A. Pendahuluan
B. Penyajian

1. Pengertian Metodologi

2. Arti dan ruang lingkup Studi Islam

3. Tujuan Studi Islam

4. Urgensi dan Signifikansi Studi Islam

5. Sejarah dan Pertumbuhan Studi islam

C. Rangkuman

D. Latihan

Bab II : Islam dan Ilmu Pengetahuan
A. Pendahuluan
B. Penyajian

1. Hubungan Ilmu, Budaya dan Agama

2. Paradigma IImu- IImu Islam

3. Sains Dunia Islam Masa KIni

C. Rangkuman

D. Latihan

Bab III : Epistemologi Islam 

A. Pendahuluan
B. Penyajian
1. Arti dan Definisi Epistemologi
2. Sumber Pengetahuan
3. Kebenaran Dalam Epistemologi Islam
C. Rangkuman
D. Latihan

Bab IV : Pendekatan dalam Studi Islam
A. Pendahuluan
B. Penyajian
1. Pendekatan Normatif
2. Pendekatan Antropologis
3. Pendekatan Sosiologis
4. Pendekatan Filosofis
5. Pendekatan Historis
6. Pendekatan Kebudayaan
7. Pendekatan Psikologis
8. Pendekatan Fenomenologis
9. Pendekatan Komparatif
10. Pendekatan Interdisipliner
C. Rangkuman
D. Latihan

Bab IV : Kajian Islam Kontemporer Perspektif Insider/outsider
A. Pendahuluan
B. Penyajian

1. Richard C. Martin 
2. Omid Safi

3. Fethulah Gulen

4. Charles J. Adams

C. Rangkuman

D. Latihan 


\section{BAB I}

\section{PENGANTAR METODOLOGI STUDI ISLAM}

\section{A. PENDAHULUAN}

Islam merupakan agama terakhir sebagai penutup semua agama yang telah ada. Ajaran-ajarannya diwahyukan Tuhan kepada manusia melalui Nabi Muhammad SAW sebagai Rasul berfungsi sebagai agama rahmatan lil "alamin. Setiap muslim berusaha menangkap dimensi yang terpancar dalam Islam melalui studi Islam. Studi Islam hadir sebagai respon sejarah atas sejumlah persoalan keagamaan yang diaalami umat Islam.

Wilayah kajian studi Islam adalah berbagai materi agama dan fenomena kehidupan beragama. Disinilah diperlukan sebuah pendekatan melalui berbagai disiplin keilmuan baik yang gersifat doktrinal - normative maupun historis - empiris untuk memperoleh pemahaman yang komprehensif dalam mengkaji studi Islam yang dikenal dengan Metodologi Studi Islam.

Seiring dinamika dan perkembangan zaman, kesempatan untuk mempelajari Studi Islam dapat melalui segala hal, berkaitan dengan persoalan tentang mempelajari Studi Islam, Islam memberikan kesempatan secara luas kepada manusia untuk menggunakan akal pikirannya secara maksimal untuk mempelajarinya. 
Pengantar metodologi studi Islam sebagai bekal bagi mahasiswa untuk memahami metodologi studi Islam secara lebih mendalam. Dalam bab ini diharapkan agar mahasiswa mampu memahami tentang pengertian dari metodologi, arti dan ruang lingkup studi Islam, tujuan studi Islam, urgensi dan signifikansi studi Islam serta sejarah dan pertumbuhan studi Islam.

\section{B. PENYAJIAN}

\section{Pengertian Metodologi}

Metodologi adalah studi tentang metode yang digunakan dalam suatu bidang ilmu untuk memperoleh pengetahuan mengenai pokok persoalan dari ilmu itu, menurut aspek tertentu dari penyelidikan. Metodologi (Science of method) dapat juga diartikan sebagai suatu pembahasan konsep teoritis atau metode yang terkait dalam suatu sistem pengetahuan.

Mengenai masalah metodologis, Harun Nasution mengatakan bahwa kelemahan di kalangan umat Islam dalam mengkaji Islam secara komprehensif adalah tidak menguasai metodologi. Metodologi berhubungan dengan proses- proses kognitif yang dituntut oleh persoalanpersoalan yang muncul dari ciri pokok studi itu. Dapat dikatakan bahwa suatu metode adalah kombinasi sistematik dari proses-proses kognitif, dengan menggunakan teknik-teknik khusus. Klasifikasi, konseptualisasi, abstraksi, penilaian, observasi, 
eksperimen, generalisasi, induksi, deduksi, argumen dari analogi, dan akhirnya pemahaman itu sendiri adalah proses-proses kognitif. Metode yang satu berbeda dengan yang lain, sesuai dengan perbedaan cara yang digunakan untuk mengatur pikiran manusia dan tugas-tugas yang dijalankan oleh pikiran tersebut. Dalam setiap metode ilmiah diandaikan adanya hubungan dekat dan sistematik antara berteori dan pengalaman. Pengamatan dan eksperimen membantu kita dengan evidensi untuk membuat generalisasi dan hipotesis- hipotesis yang dites (dibenarkan atau disalahkan), lewat deduksi- deduksi daripadanya serta membandingkan semua ini dengan akibat-akibat dari pengamatan-pengamatan dan eksperimen- eksperimen lebih lanjut.

\section{Arti dan Ruang Lingkup Studi Islam}

\section{a. Arti Studi Islam}

Secara etimologi, Studi Islam merupakan gabungan dari dua kata yaitu Studi dan Islam. Studi berasal dari kata Study, yang berarti mempelajari atau mengkaji. Lester Crow dan Alice Crow menyebutkan bahwa studi adalah kegiatan yang diusahakan secara sengaja dengan maksud untuk memperoleh keterangan, mencapai pemahaman yang lebih besar atau meningkatkan suatu keterampilan. Sedangkan menurut Muhammad Hatta, Studi adalah mempelajari sesuatu untuk mengerti kedudukan masalahnya, mencari pengetahuan tentang sesuatu 
dalam hubungan sebab akibatnya, ditinjau dari jurusan tertentu dan dengan metode tertentu pula. Sedangkan Islam berasal dari bahasa Arab, yaitu kata salima dan aslama. Salima mengandung arti selamat, tunduk, dan berserah. Sedangkan aslama juga mengandung arti kepatuhan, ketundukan, dan berserah.

Dalam kajian Islam, studi Islam lebih dikenal dengan istilah Islamic Studies yang diartikan sebagai suatu usaha mendasar dan sistematis untuk mengetahui dan memahami serta membahas secara mendalam seluk beluk yang berhubungan dengan agama Islam, baik ajaran-ajarannya, maupun praktek pelaksanaannya secara nyata dalam kehidupan sehari-hari sepanjang sejarah.

Objek dari Studi Islam bisa berupa aktivitas dan program pengkajian serta penelitian terhadap agama yang dilakukan oleh institusi pengkajian Islam, baik formal seperti perguruan tinggi maupun non formal seperti forum kajian dan halaqoh.

\section{b. Ruang Lingkup Studi Islam}

Berdasarkan sifat dan karakteristik Antara ilmu pengetahuan dan agama, akhirnya memunculkan perselisihan pendapat tentang apakah islam itu termasuk kedalam sains atau ilmu pengetahuan. IImu pengetahuan dapat dikritisi, sedangkan agama dengan alasan apapun tidak dapat dikritik karena merupakan ajaran dari tuhan yang memiliki kebenaran yang mutlak tidak relatif. 
Sehingga terjadi dikotomi Antara antara sains islam dengan studi islam. Sains islam mencakup berbagai pengetahuan modern seperti kedokteran, astronomi, matematika, fisika, dan sebagainya yang dibangun atas arahan nilai nilai islami. Sementara studi islam adalah pengetahuan yang dirumuskan dari ajaran islam yang dipraktikkan dalam sejarah dan kehidupan manusia, sedang pengetahuan agama adalah pengetahuan yang sepenuhnya diambil dari ajaran ajaran allah dan Rasulnya secara murni tanpa dipengaruhi sejarah, seperti ajaran tentang akidah, ibadah, membaca al Qur'an dan akhlak.

Nuansa Kajian keislaman terkesan mengikuti selera pengkajinya. Karena pada dasarnya pengkajian keislaman mengikuti pada wawasan dan keahlian para pengkajinya. Dalam tradisi Barat (orientalism scholar), ruang lingkup kajian Islam meliputi pembahasan mengenai ajaran, doktrin, pemikiran, teks, sejarah dan institusi keislaman. Pada awalnya ketertarikan sarjana Barat terhadap pemikiran Islam lebih karena kebutuhan atas penguasaan daerah koloni. Mengingat daerah koloni pada umumnya adalah negara-negara yang banyak di domisili warga negara yang beragama Islam, sehingga mau tidak mau mereka harus paham tentang budaya lokal. Kasus ini dapat dilihat pada perang Aceh, Snouck Hurgronje (sarjana Belanda) telah mempelajari Islam terlebih dahulu sebelum diterjunkan dilokasi 
dengan asumsi ia telah memahami budaya dan peradaban masyarakat Aceh yang mayoritas beragama Islam. Islam dipelajari oleh Snock Hurgronje dari sisi landasan normatif maupun praktik bagi para pemeluknya, kemudian dibuatlah rekomendasi kepada para penguasa kolonial untuk membuat kebajikan yang berkaitan dengan kepentingan umat Islam.

Islam dipahami dari sisi ajaran, doktrin dan pemahaman masyarakat dengan asumsi dapat diketahui tradisi dan kekuatan masyarakat setempat. Setelah itu, pemahaman yang telah menjadi input bagi kaum orientalis diambil sebagai dasar kebajikan oleh para penguasa kolonial yang tentunya lebih menguntungkan mereka dibandingkan dengan rakyat banyak di wilayah jajahannya. Hasil studi ini sesungguhnya lebih menguntungkan kaumpenjajah. Atas dasar masukan ini para penguasa kolonial dapat mengambil kebijakan daerah koloni dengan mempertimbangkan budaya lokal. Atas masukan ini, para penjajah mampu membuat peta kekuatan sosial masyarakat terjajah sesuai dengan kepentingan dan keuntungannya.

Menurut Amin Abdullah terdapat tiga wilayah keilmuan agama Islam yang dapat menjadi Objek Studi Islam, yaitu :

1. Wilayah-wilayah teori keilmuan yang dirancang dan disusun sistematika dan metodologinya 
oleh para ilmuan, para ahli, dan para ulama sesuai bidang kajiannya masing-masing. Apayang ada pada wilayah ini sebenarnya tidak lain dan tidak bukan adalah "teori-teori" keilmuan agama Islam, baik secara deduktif dari nash-nash atau teks-teks wahyu, maupun secara induktif dari praktik-praktik keagamaan yang hidup

2. Wilayah praktik keyakinan dan pemahaman terhadap wahyu yang telah diintrepretasikan sedemikian rupa oleh para ulama, tokoh panutan masyarakat pada umumnya. Wilayah praktik ini umumnya tanpa melalui klarifikasi dan penjernihan teoritik keilmuan yang dipentingkan disini adalah pengalaman.

3. Telaah kritis yang lebih populer disebut metadiscourse, terhadap sejarah perkembangan jatuh bangunnya teori-teori yang disusun oleh kalangan ilmuan dan ulama pada lapis kedua. Wilayah pada lapis ketiga yang kompleks dan sophisticated inilah yang sesungguhnya dibidangi oleh filsafat ilmu-ilmu keislaman.

Sedangkan Muhammad Nurhakim menyatakan bahwa memang tidak semua aspek agama, khususnya Islam dapat menjadi objek studi. Dalam konteks khusus 
studi Islam, ada beberapa aspek tertentu dari Islam yang dapat menjadi objek studi, yaitu :

1. Islam sebagai Doktrin dari Tuhan yang kebenarannya bagi para pemeluknya sudah final, dalam arti absolut, dan diterima secara apa adanya.

2. Sebagai gejala budaya yang berarti seluruh apa yang menjadi kreasi manusia dalam kaitannya dengan agama, termasuk pemahaman orang terhadap doktrin agama.

3. Interaksi sosial yaitu realitas umat Islam.

M. Atho' Mudzhar menyatakan bahwa objek kajian Islam adalah substansi ajaran-ajaran Islam, seperti kalam, fiqih dan tasawuf. Dalam aspek ini agama lebih bersifat penelitian budaya, hal ini mengingat bahwa ilmu-ilmu keislaman semacam ini merupakan salah satu bentuk doktrin yang dirumuskan oleh penganutnya yang bersumber dari wahyu Allah melalui proses penawaran dan perenungan. Ketika seseorang mempelajari bagaimana ajaran Islam tentang sholat, haji, zakat, haji, tentang konsep ke- Esa-an Allah, tentang argumen adanya Tuhan, tentang aturan etika dan nilai moral dalam Islam, berarti sedang mempelajari Islam sebagai gejala budaya. 


\section{Tujuan Studi Islam}

Sebagai media transfer pengetahuan, Studi Islam sangat penting dalam pengembangan ilmu pengetahuan. Secara normative tujuan yang ingin dicapai dalam pengembangan studi Islam meliputi tiga dimensi, yaitu:

1. Dimensi spiritual, yaitu iman, takwa, dan akhlak mulia (yang tercermin dalam ibadah dan muamalah). Dimensi spiritual ini tersimpul dalam satu kata yaitu akhlak mulia. Dimensi ini sebagai tujuan utama studi Islam.

Menurut Said Aqil Husein al-Munawar, akhlak merupakan alat control psikis dan sosial bagi individu dan masyarakat. Tanpa akhlak, manusia akan berada dalam kumpulan binatang yang tidak memliliki tata nilai dalam kehidupannya. Rasulullah saw adalah sumber akhlak yang hendaknya diteladani oleh orang mukmin, seperti tercermin dalam sabdanya:

"Sesungguhnya aku diutus untuk menyempurnakan akhlak yang mulia".

2. Dimensi budaya, yaitu kepribadian yang mantap dan mandiri, tanggung jawab kemasyarakatan dan kebangsaan. Dimensi ini secara universal menitikberatkan pada pembentukan kepribadian muslim sebagai individu yang diarahkan kepada peningkatan dan pengembangan faktor dasar 
(bawaan) dan factor ajar (lingkungan) dengan berpedoman kepada nilai- nilai keislaman.

3.Dimensi kecerdasan yang membawa kemajuan, yaitu cerdas, aktif, disiplin, inovatif, produktif, dan sebagainya.

Upaya yang dilakukan dalam studi Islam tentunya tidak cukup di ruang kelas atau disekolah saja. Sebab lembaga yang mempunyai peran sesungguhnya adalah keluarga. Sebagai unit masyarakat terkecil, keluarga memiliki dampak langsung terhadap kehidupan peserta didik dan masyarakat itu sendiri. Disinilah anak mendapatkan imu pengetahuan pertama kalinya sebelum mendapatkan dari lembaga lain.

Studi Islam sebagai sebuah kajian secara sistematis terhadap Islam memiliki sebuah tujuan yang harus ditetapkan secara konkret. Secara garis besar tujuan studi islam adalah:

1. Mempelajari secara mendalam tentang hakikat islam, bagaimana posisinya dengan agama lain, dan bagaimana hubungannya dengan dinamika perkembangan yang terus berlangsung.

2. Mempelajari secara mendalam terhadap sumber dasar ajaran agama islam yang tetap abadi dan dinamis serta aktualisasinya sepanjang sejarah.

3. Mempelajari secara mendalam terhadap pokok isi ajaran islam yang asli, dan bagaimana 
operasionalisasinya dalam pertumbuhan budaya dan peradaban islam sepanjang sejarah.

4. Mempelajari secara mendalam terhadap prinsip-prinsip dan nilai-nilai dasar ajaran islam dan bagaimana perwujudannya dalam membimbing dan mengarahkan serta mengontrol perkembangan budaya dan peradaban manusia pada zaman modern ini.

Dengan menyimak terhadap 4 tujuan ini studi islam diharapkan akan lebih jelas arahnya. Tujuan ini menjadi semacam titik yang akan dituju dengan berbagai sarana dan metode untuk mencapainya. Dengan kerangka tujuan semacam ini, studi islam diharapkan tidak sekedar sebagai sebuah wawasan normatif, tetapi juga konstektual, aplikatif, dan memberikan kontribusi konkret terhadap dinamika dan perkembangan yang ada.

\section{Urgensi dan Signifikansi Studi Islam}

Situasi keberagamaan di Indonesia cenderung menampilkan kondisi yang formalistik (simbolik). Sehingga muncul formalisme (simbol) keagamaan yang mementingkan "bentuk" (formalisme) daripada "isi" (substansi). Sedemikian rupa, sehingga agama kurang dipahami sebagai 'seperangkat paradigma moral dan etika' yang bertujuan membebaskan manusia dari kebodohan, 
keterbelakangan, dan kemiskinan. Selain itu, keberagamaan formalistik cenderung individualistik.

Urgensi Studi Islam adalah mengubah pemahaman dan penghayatan masyarakat muslim di Indonesia secara khusus, dan masyarakat beragama di Indonesia secara umum. Sasaran pokoknya adalah: pertama, format formalisme keagamaan perlu dirubah menjadi format keagamaan yang substantif (mengutamakan nilai atau makna); kedua, Studi Islam diharapkan melahirkan "suatu komunitas" yang mampu melakukan perbaikan internal (konflik intern umat beragama) dan eksternal (kerukunan antar umat beragama dengan) umat Islam.

Menurut Bambang Sugiharto dalam Atang Abdul Hakim, setiap agama di dunia saat ini sedang menghadapi tiga macam tantangan, yaitu:

1. Agama ditantang untuk tampil sebagai suara moral yang autentik dalam menghadapi persoalan kontemporer.

2. Agama harus menghadapi kecenderungan pluralisme; kemudian mengolahnya dalam kerangka "teologi baru".

3. Agama (harus) tampil sebagai pelopor perlawanan terhadap segala bentuk penindasan dan ketidakadilan. 
Sedangkan problem yang dihadapi oleh masingmasing agama antara lain:

1. Kemelut dalam masing-masing tubuh agama seringkali muncul ke permukaan.

2. Paham tentang kemutlakan Tuhan, memudahkan orang untuk mengidentikan dengan kemutlakan (ajaran) agamanya.

3. Tindak kekerasan terhadap pemeluk agama lain justru dianggap sebagai keutamaan moral.

4. Agama (rawan) ditumpangi kepentingan politik, ekonomi, dan kultur kelompok atau pribadi tertentu.

Dari berbagai problem agama diatas, menyebabkan posisi agama serba sulit. Di satu pihak, agama diharapkan menjadi problem solver terhadap situasi yang diakibatkan oleh modernitas. Di pihak lain, konflik antar agama dan konflik intern pemeluk agama belum berhasil diselesaikan.

Sementara itu, Komarudin Hidayat membuat tipologi sikap keberagamaan bangsa Indonesia sebagai berikut:

1. Bersikap eksklusif, yakni pandangan bahwa ajaran (agama) yang benar hanyalah ajaran agama yang dipeluknya.

2. Bersikap inklusif, yakni pandangan bahwa di luar agama yang dipeluknya terdapat juga kebenaran, tetapi tidak sesempurna agama yang dianutnya. 
3. Berskap pluralis, yakni pandangan bahwa pluralitas (keanekaragaman) ajaran agama sebagai realita yang lumrah.

4. Bersikap eklektif, yakni sikap keberagamaan yang berusaha memilih dan mempertahankan berbagai ajaran agama yang dipandang baik dan cocok bagi dirinya.

5. Bersikap universal, yakni anggapan bahwa pada dasarnya semua ajaran agama adalah satu dan sama. Hanya karena faktor historis dan antropologis, agama-agama tampil dalam format plural.

\section{Sejarah dan Pertumbuhan Studi Islam}

Di kalangan Umat Islam, Studi Islam digunakan untuk memahami ajaran-ajaran Islam agar mereka dapat melaksanakannya secara benar, serta menjadikannya sebagai pedoman hidup. Sedangkan di luar kalangan umat Islam, Studi Islam digunakan untuk mempelajari selukbeluk agama dan praktek keagamaan yang berlaku di kalangan umat Islam, yang hanya terbatas sebagai ilmu pengetahuan belaka.

Sejak Islam dikenal oleh manusia penghuni bumi (Abad ke-7), orang-orang Eropa dan Amerika (Kristen) merasa serba tak enak. Hal ini terjadi karena: Pertama, Islam merupakan agama besar yang muncul dari akar historis yang sama (antara Kristen, Yahudi, dan Islam). 
Kedua, Islam dipandang sebagai tantangan dan ancaman terhadap Teologi Kristen. Disebut tantangan, karena Islam menolak doktrin Kristen tentang Yesus. Islam menolak Konsep Trinitas. Dikatakan sebagai ancaman, karena ekspansi militer Arab Muslim terhadap wilayah Eropa (Abad 17). Islam dipandang berbahaya bagi umat Kristen, dan bahaya itu tidak dapat diramalkan maupun diukur. Selain itu, ketegangan Islam dan Barat karena terjadi psiko-keagamaan bawah sadar di kalangan Kristen.

Studi Islam mencerminkan suatu transmisi doktrin-doktrin keagamaan dari generasi ke generasi, dengan menjadikan tokoh-tokoh agarna, mulai dari Rasulullah sampai dengan ustazd (guru agama) dan para da'i sebagai the living mediators. Secara kelembagaan, proses ini berlangsung di berbagai instirusi, mulai keluarga, masyarakat, masjid, kuttab, madrasah, pesantren. sampai dengan al-jami'ah. Di samping proses transmisi, kajian agama juga merupakan usaha bagi para pemeluk agama yang bersangkutan untuk memberikan respons terhadap ajaran, ideologi, atau pemikiran dari luar agama yang diyakininya.

Pengertian-pengertian di atas memberikan arahan bahwa studi Islam merupakan kajian keislaman yang melampaui batas-batas Islam pada aspek normativitas ajaran semata, namun juga memasuki aspek historisitasnya. Studi Islam (Dirasah/slamiyah/ Islamic 
Studies) diharapkan mampu menghantarkan terhadap pemahaman Islam yang komprehensif/ kaffah. Pemahaman yang bersifat parsial akan menjadikan pengertian Islam akan salah dipahami Harun Nasution pada saat menjelaskan di dalam pendahuluan dari bukunya yang berjudul Islam Ditinjau dari Berbagai Aspeknya, Menurutnya bahwa di kalangan masyarakat Indonesia terdapat kesan bahwa Islam bersifat sempit. Kesan itu timbul dari salah pengert ian tentang hakikat Islam. Kekeliruan paham ini terdapat bukan hanya di kalangan umat bukan Islam (non-Muslim), tetapi juga di kalangan sebagian agamawan-agamawan Islam.

Menurut Harun Nasution, kekeliruan paham itu terjadi diakibatkan karena kurikulum pendidikan agama Islam yang banyak dipakai di Indonesia ditekankan pada pengajaran ibadah, fikih, tauhid, tafsir, hadis dan Bahasa Arab. Oleh karena itu, Islam di Indonesia banyak dikenal dari aspek ibadah, fikih dan tauhid saja. Hal ini memberi pengetahuan yang sempit tentang Islam. Dalam Islam sebenamya terdapat aspek-aspek selain dari yang $d$ isebut di atas, seperti aspek teologi, aspek ajaran spiritual dan moral, aspek sejarah kebudayaan, aspek politik aspek hukum, aspek lembaga-lembaga kemasyarakatan, aspek mistisisme dan tarekat, aspek falsafat, aspek ilmu pengetahuan dan aspek pemikiran serta usaha-usaha pembaruan dalam Islam. 
Studi terhadap Islam dalam realitasnya tidak hanya monopoli intern umat Islam saja. Akan tetapi juga dilakukan oleh orang-orang yang berada di luar Islam. Oleh sebab itu, Studi Islam di sini akan dilakukan dengan menggunakan dua sisi pendekatan, yaitu dari intern umat Islam (insider) dan juga dari luar Islam (outsider). Hal ini dalam rangka untuk mempertegas perbedaan yang sering dilakukan umat Ilslam sendiri ataupun oleh dunia akademik Barat. Para ahli studi keislaman di luar kalangan umat Islam tersebut dikenal dengan kaum orientalis (istisyraqiy), yairu orang-orang Barat yang mengadakan studi temang dunia Timur, termasuk di kalangan dunia orang Islam. Dalam praktiknya studi keislaman yang dilakukan oleh mereka:, terutama pada masa awal-awal Islam mereka melakukan studi dunia Timur, lebih mengarahkan dan menekankan kelemahankelemahan ajaran agama Islam dan praktik-praktik pengalaman ajaran agama Islam dalam kehidupan seharihari umat Islam. Namun demikian, pada masa- masa akhir-akhir ini banyak juga eli antara para orientalis yang memberikan pandangan -pandangan yang qbjektif dan be,rsifat ilmiah terhadap agama Jslan1dan umatnya. Tentu saja pandangan-pandangan yangdemikian itu akan bisa bermanfaat bagi pengembangan-pengembangan studi-studi keislaman di kalangan umat Islam sendiri.

Memasuki abad kedua puluh masehi, keadaan dunia ditandai oleh kemajuan yang dicapai oleh barat dalam 
bidang ilmu pengetahuan dan teknologi dengan segala implikasinya, yaitu berupa penjajahan mereka atas dunia islam. Negara negara yang dahulu masuk ke dalam hegemoni islam seperti spanyol, india, sisilia, dan sebagainya sudah mulai melepaskan diri dari islam dan berdiri sendiri sebagai negara yang sepenuhnya berada diluar ideologi islam. Demikian pula negara negara yang sepenuhnya dikuasai islam juga sudah banyak yang menjadi jajahan bangsa bangsa lain. Negara negara tersebut antara lain mesir, turki, malaysia, dan Indonesia.

Menghadapi keadaan yang demikian itu, umat islam mencari sebab sebabnya. Sebab sebab tersebut yang utama diantaranya karena umat islam tertinggal dalam bidang ilmu pengetahuan dan teknologi serta adanya perpecahan.

Dikalangan umat islam paling kurang timbul tiga sikap menghadapi keterbelakangan dalam bidang ilmu pengetahuan tersebut sebagai berikut.

Sikap yang didasarkan pada asumsi bahwa ilmu pengetahuan yang berasal dari barat sebagai ilmu pengetahuan yang sekular dan harus ditolak.

1.Sikap yang didasarkan pada asumsi bahwa ilmu pengetahuan yang berasal dari barat sebagai ilmu yang bersifat netral. Karenanya ilmu tersebut harus diterima apa adanya tanpa disertai rasa curiga dan sebagainya.

2.Sikap yang didasarkan pada asumsi bahwa ilmu pengetahuan yang berasal dari barat sebagai ilmu yang 
bersikap sekular dan materialisme. Namun dapat diterima oleh umat islam dengan terlebih dahulu dilakukan proses islamisasi.

Ketiga sikap tersebut satu dan lainnya memiliki pengaruh sendiri dimasyarakat dengan segala implikasinya. Studi dalam bab ini adalah penjabaran lebih lanjut dari sikap yang ketiga sebagaimana tersebut diatas, yaitu sikap mengislamkan ilmu pengetahuan.

Islamisasi ilmu pengetahuan pada hakikatnya adalah suatu upaya untuk mentransformasikan nilai nilai keislaman ke dalam berbagai bidang kehidupan manusia, khususnya ilmu pengetahuan. Dengan Islamisasi ilmu pengetahuan dapat diketahui dengan jelas, bahwa islam bukan hanya mengatur segi segi ritualitas dalam arti shalat, puasa, zakat, dan haji melainkan sebuah ajaran yang mengintegdrasikan segi segi kehidupan duniawi termasuk ilmu pengetahuan dan teknologi. Ditengah tengah masyarakat yang masih dilanda krisis dalam berbagai bidang kehidupan seperti sekarang ini, islamisasi ilmu pengetahuan semakin dipandang relevan daya antisipatifnya.

Ditengah tengah perdebatan disekitar setuju atau tidak setuju dengan islamisasi ilmu pengetahuan tersebut, tampaknya islamisasi ilmu pengetahuan tersebut pada akhirnya merupakan suatu keharusan. Lahirnya industri perbankan yang berbasiskan syariat seperti yang 
dipraktikkan pada bank muamalat Indonesia (BMI), bank Syariah Mandiri, dan sebagainya menunjukkan pentingnya nilai nilai islam terintergrasi dalam sistem perekonomian yang dikembangkan masyarakat. Demikian pula praktik kehidupan kenegaraan yang semakin menuntut perlunya ditegakkan asas keadilan, kejujuran, demokrasi, transparasi, dan sebagainya menunjukkan bahwa nilai nilai islam perlu diintegrasikan ke dalam praktik kenegaraan. Demikian pula munculnya universitas Islam Negeri (UIN) syarif Hidayatullah Jakarta yang ditujukan pada upaya mengintergrasikan ilmu agama dan umum, juga merupakan bukti perlunya program islamisasi ilmu pengetahuan itu dilaksanakan.

Munculnya pusat-pusat Studi Islam di Eropa, pada mulanya dikembangkan untuk kepentingan politik dan perdagangan. Tetapi akhir-akhir ini justru meningkat untuk kepentingan ilmu pengetahuan dan dakwah. Pusat-pusat Studi Islam yang dimaksud antara lain:

1. Di Chicago University (Amerika Serikat), menekankan pada bidang: pemikiran Islam, bahasa Arab, naskah klasik, serta bahasa Islam non-Arab.

2. Di Unversity of California (Amerika Serikat), menekankan pada bidang: doktrin dan ajaran Islam, bahasa Arab, bahasa non-Arab, serta ilmu-ilmu sosial.

3. Di Inggris, menekankan pada bidang: studi ketimuran dan Afrika, serta Bahasa dan kebudayaan Asia Afrika. 
4. Di Mc Gill Univercity (Kanada), menekankan pada bidang: Budaya dan peradaban Islam, Ajaran Islam dan masyarakat muslim, serta bahasa kaum muslim.

Khusus mengenai pusat Studi Islam di kalangan Umat Islam, antara lain terdapat di:

1. Spanyol, ada Universitas Cordova

2. Mesir, ada Universitas Al-Azhar

3. Baghdad (Irak), ada Madrasah Nizhamiyah

4. Arab Saudi, ada Universitas Ummul Quro

5. Iran, ada Universitas Teheran

6. Syiria, ada Universitas Damaskus

7. Malaysia, ada Universitas Kebangsaan Malaysia.

Sedangkan studi Islam di Indonesia telah berkembang pesat di Universitas Islam (negeri dan swasta), Institut Agama Islam (negeri dan swasta), Sekolah Tinggi Agama Islam (negeri dan swasta), serta pusat-pusat pengkajian Islam lainnya.

\section{RANGKUMAN}

1. Metodologi adalah studi tentang metode yang digunakan dalam suatu bidang ilmu untuk memperoleh pengetahuan mengenai pokok persoalan 
dari ilmu itu, menurut aspek tertentu dari penyelidikan.

2. Studi Islam lebih dikenal dengan istilah Islamic Studies yang diartikan sebagai suatu usaha mendasar dan sistematis untuk mengetahui dan memahami serta membahas secara mendalam seluk beluk yang berhubungan dengan agama Islam, baik ajaranajarannya, maupun praktek pelaksanaannya secara nyata dalam kehidupan sehari-hari sepanjang sejarah.

3. Objek dari Studi Islam bisa berupa aktivitas dan program pengkajian serta penelitian terhadap agama yang dilakukan oleh institusi pengkajian Islam, baik formal seperti perguruan tinggi maupun non formal seperti forum kajian dan halaqoh.

4. Secara normative tujuan yang ingin dicapai dalam pengembangan studi Islam meliputi tiga dimensi, yaitu:
a. Dimensi spiritual
b. Dimensi budaya
c. Dimensi kecerdasan

5. Urgensi Studi Islam adalah mengubah pemahaman dan penghayatan masyarakat muslim di Indonesia secara khusus, dan masyarakat beragama di Indonesia secara umum.

6. Studi Islam digunakan untuk memahami ajaran-ajaran Islam agar mereka dapat melaksanakannya secara 
benar, serta menjadikannya sebagai pedoman hidup (insider). Sedangkan di luar kalangan umat Islam, Studi Islam digunakan untuk mempelajari seluk-beluk agama dan praktek keagamaan yang berlaku di kalangan umat Islam, yang hanya terbatas sebagai ilmu pengetahuan belaka (Outsider).

\section{LATIHAN}

1. Jelaskan pengertian metodologi berdasarkan analisa anda !

2. Deskripsikan ruang lingkup Islamic Studies menurut beberapa pendapat para ahli!

3. Bagaimana pendapat anda tentang insider dan outsider?

4. Sejauhmana pertumbuhan studi Islam hingga masa sekarang? 


\section{BAB II}

\section{ISLAM DAN ILMU PENGETAHUAN}

\section{A. PENDAHULUAN}

Manusia memiliki pengetahuan yang merupakan nalar untuk melaksanakan segala akrivitas dalam kehidupan sehari- hari. Tanpa pengetahuan manusia akan mengalami kendala dalam menyelesaikan persoalannya. Pengetahuan dimulai dari rasa ingin tahu, yang merupakan ciri khas manusia karena manusia merupakan makhluk yang tidak pernah puas dalam mengembangkan pengetahuan yang dilakukan secara sungguh-sungguh.

Pengetahuan merupakan khazanah kekayaan mental yang secara langsung atau tidak langsung turut memperkaya kehidupan kita. Pengetahuan merupakan sumber jawaban bagi berbagai pertanyaan yang muncul dalam kehidupan .

Islam mengajarkan kehidupan yang dinamis dan progresif, menghargai akal pikiran pengembangan ilmu pengetahuan dan teknologi. Dewasa ini manusia menghadapi berbagai macam persoalan yang membutuhkan pemecahan segera. Situasi yang penuh dengan problematik di dunia modern justru disebabkan oleh perkembangan pemikiran manusia sendiri.

Akhir dari materi ini, mahasiswa diharapkan mampu memahami dan mendeskripsikan hubungan 
ilmu, budaya dan agama, Paradigma IImu-IImu Islam serta Sains Dunia Islam Masa Kini.

\section{B. PENYAJIAN}

\section{Hubungan Ilmu, Budaya dan Agama}

Ilmu berasal dari kata 'alima (bahasa Arab) yang berarti tahu. RALP ROSS dan ERNEST VAN DEN HAAG menulis: "Science is empirical, rational, general and cumulative; and it is all four at once" (IImu ialah yang empiris, yang rasional, yang umum dan bertimbunbersusun; dan keempat-empatnya serentak).

Prof. Drs HARSOJO, Guru besar antropologi di Universitas Pajajaran, menerangkan bahwa ilmu itu:

- Merupakan akumulasi pengetahuan yang disistemasikan;

- Suatu pendekatan atau suatu metode pendekatan terhadap seluruh dunia empiris, yaitu dunia yang terikat oleh faktor ruang dan waktu, dunia yang pada prinsipnya dapat diamati, oleh pancaindra manusia;

- Suatu cara menganalisa yang mengijinkan kepada ahliahlinya untuk menyatakan sesuatu proposisi dalam bentuk "jika...;maka..".

Pengertian Agama, secara etimologi berasal dari dua kata: $a=$ tidak dan gama $=$ kacau. POERWADARMINTA dalam kamusnya menerangkan bahwa agama adalah segenap kepercayaan (kepada Tuhan, Dewa, dsb) serta dengan kebaktian dan kewajiban-kewajiban yang bertalian dengan kepercayaan itu. 
Sedangkan budaya adalah suatu cara hidup yang berkembang, dan dimiliki bersama oleh sebuah kelompok orang dan diwariskan dari generasi ke generasi. Budaya bersifat kompleks, abstrak, dan luas. Budaya terbentuk dari banyak unsur, diantaranya sistem agama, politik, adat istiadat, bahasa, karya seni, bangunan, pakaian, unsur yang lainnya.

Hubungan antara IImu, agama dan budaya sangat berkaitan. Ilmu, dengan metodenya sendiri, mencari kebenaran tentang alam dan manusia. Agama, dengan karakternya sendiri mampu memberikan jawaban atas segala persoalan yang dipertanyakan manusia, baik tentang alam, manusia ataupun Tuhan yang tidak terjawab oleh ilmu. Dengan kekuatan akal (ilmu)nya, manusia menghampiri kebenaran. Agama tanpa ilmu dapat menyebabkan musyrik.

M. Amin Abdullah menyatakan bahwa hubungan antara agama dan ilmu pengetahuan tampaknya menjadi pandangan dikotomis. Keduanya ibarat minyak dan air, dua entitas yang tidak bisa bersatu kembali dan dipisahkan. Karena "sengketa ini" ilmu pengetahuan mencoba merangkul konsep-konsep ag- ama dan etika agar ilmu pengetahuan-teknologi memiliki nuansa yang manusiawi. Konflik antara keduanya memaksa kaum Muslim intelektual membuat "jembatan epistemologi" untuk mendamaikan sains dan agama.

Islam demikian kuat mendorong manusia agar 
memiliki ilmu pengetahuan dengan cara menggunakan akalnya untuk berpikir, merenung dan mencari jalan keluar dengan cara riset. Islam memberikan kedudukan sangat tinggi kepada akal manusia. Hal ini dapat dilihat dari beberapa ayat Al Qur'an yang menganjurkan kepada menusia agar selalu menggunakan akalnya untuk menalar dan memahami berbagai macam persoakn Pengetahuan lewat akal disebut pengetahuan aqli. Lawannya merupakan pengetahuan naqli. Penalaran merupakan suatu proses berpikir yang membuahkan pengetahuan. Agar pengetahuan yang dihasilkan penalaran itu mempunyai dasar kebenaran, maka proses berpikir itu harus dilakukan dengan cara dan metode tertentu. Suatu penarikan kesimpulan baru dianggap sahih (valid) kalau proses penarikan kesimpulan ini disebut dengan logika, di mana logika secara luas dapat didefinisikan sebagai pengkajian untuk berpikir secara sahih.

Hal ini dapat dilihat dari lima ayat pertama Surah Al'Alaq yang diturunkan Allah kepada Nabi Muhammad saw. "Bacalah dengan (menyebut) nama Tuhanmu yang menciptakan, Dia telah menciptakan manusia dari segumpal darah. Bacalah, dan Tuhanmulah yang Maha Pemurah, Dialah yang mengajarkan manusia menulis dengan pena, Dia mengajarkan kepada manusia apa yang tidak diketahuinya". (QS. Al-Alaq (96): 1-5).

Pada ayat tersebut terdapat kata iqra' sebanyak dua 
kali. Kata tersebut menurut A. Baiguni, selain berarti membaca dalam arti biasa, juga berarti menelaah, mengobservasi, membandingkan, mengukur, mendeskripsikan, menganalisis, dan menyimpulkan secara induktif. Hal itu merupakan salah satu cara yang dapat mengembangkan ilmu pengetahuan. Demikian pentingnya ilmu hingga Islam memandang bahwa orang menuntut ilmu sama nilainya dengan jihad di jalan Allah.

Sedangkan hubungan agama dengan budaya, agama tidak akan di anut oleh umatnya tanpa budaya. Agama tidak tersebar tanpa budaya, begitupun sebaliknya, budaya akan tersesat tanpa agama. Agama memiliki posisi yang cukup signifikan dalam kehidupan bermasyarakat. Negara mengakui keberadaan agama dan melindungi kebebasan masyarakat dalam melaksanakan ajaran agamanya.

\section{Paradigma IImu- IImu Islam}

Nurcholis Madjid pernah menjelaskan tentang hubungan baik organik antara iman dan ilmu dalam islam. Menurutnya, IImu adalah hasil pelaksanaan perintah Tuhan untuk memeperatikan dan memahami alam raya ciptaanNya, sebagai manifetasi atau penyingkapan tabir akan rahasia-Nya.

Antara iman dan ilmu tidak dapat dipisahkan, meskipun dapat dibedakan (satu dengan lainnya). Istilah tidak dapat dipisahkan karena: (1) iman dapat mendorong 
menghasilkan ilmu pengetahuan; (2) iman mampu membimbing ilmu dengan pertimbangan moral dan etis; (3) iman bersandar kepada sikap membenarkan sesuatu; sedangkan (4) ilmu bersandar dari hasil observasi terhadap alam; (5) ilmu disusun melalui proses penalaran rasional; dan (6) obyek iman berada di luar jangkauan pengalaman manusia, seperti kehidupan sesudah mati.

Dalam proses mengenal tuhan, manusia hanya menerima tanda-tanda yang diberikan-Nya. Dalam bahasa arab, kata "Ilmu" satu akar kata dengan kata "alam" (bendera atau lambang), "alamah" (alamat atau pertanda), dan "a'lam” (jagad raya, univers). Ketiga harus diketahui atau dimaklumi, yakni menjadi objek pengetahuan.

Manusia hendak menyikap rahasia Allah tanda nya berupa jagad raya, menggunakan perangkat berupa ilmu perhitungan "faraidz" yang berupa matematika, ilmu fisik, seperti ilmu fisika, kimia, geografi, geologi, astronomi dan falaq. Manusia hendak nya memikirkan tanda-tanda kekuasaan Allah yaitu berupa manusia, yang akan menghasilkan berbagai ilmu. Dari segi perhitungan fisik, pendalaman terhadap struktur tubuh manusia melahirkan ilmu biologi dan kedokteran. Sedangkan aspek psikis manusia memunculkan ilmu psikologi. Apabila di kaji secara kolegtif atau kelompok, kajian terhadap manusia menghasilkan ilmu sosiologi, ilmu lingkungan, komunikasi, hukum, ekonomi, sejarah, politik, dan sebagainya. 
Manusia yang mampu melihat tanda-tanda kekuasaan Allah antara lain:

1. Mereka yang berfikir mendalam,

2. Mereka yang memiliki kesadaran tentang makna hidup abadi,

3. Mereka yang menyadari bahwa penciptaan alam raya sebagai wujud bukti kekuasaan Allah,

4. Mereka yang menyadari bahwa kebahagiaan dapat hilang karena pandangan negatif/ pesimis.

Islam lebih banyak memperhatikan aspek sosial daripada kehidupan ritual. Sanksi-sanksi dalam ajaran Islam (ibadah) berupa nilai-nilai sosial ekonomis. Seperti: potong kambing, bayar zakat, dan bayar fidyah.

Perkembangan iptek membawa kemajuan di bidang politik, ekonomi, dan sosial (peradaban), tetapi umat manusia menjadi tertawan (terasing) oleh hasil ciptaannya sendiri. Karena itu, diperlukan Iptek yang mampu membebaskan manusia modern dari problema tersebut. Iptek yang dimaksud adalah ilmu sosial profetik (ilmu pengetahuan sosial yang digali dari nilai-nlai agama Islam). Ilmu sosial profetik adalah ilmu sosial yang tidak hanya menjelaskan dan mengubah fenomena sosial, tetapi juga memberi petunjuk ke arah transformasi sosial. Ke arah mana, untuk siapa, dan oleh siapa? Cita-cita profetik yaitu: kemanusiaan, liberasi, dan transendensi. 
Orang Islam memandang bahwa berkembangnya berbagai sains (ilmu alam dan ilmu sosial) sebagai bukti adanya kebenaran yang fundamental dalam Islam. Sumbangan Islam terhadap perkembangan iptek antara lain dalam bidang Matematika, Astronomi, Kimia, dan Optik.

Menurut Nurcholis Madjid, Paradigma IImu-IImu Islam antara lain:

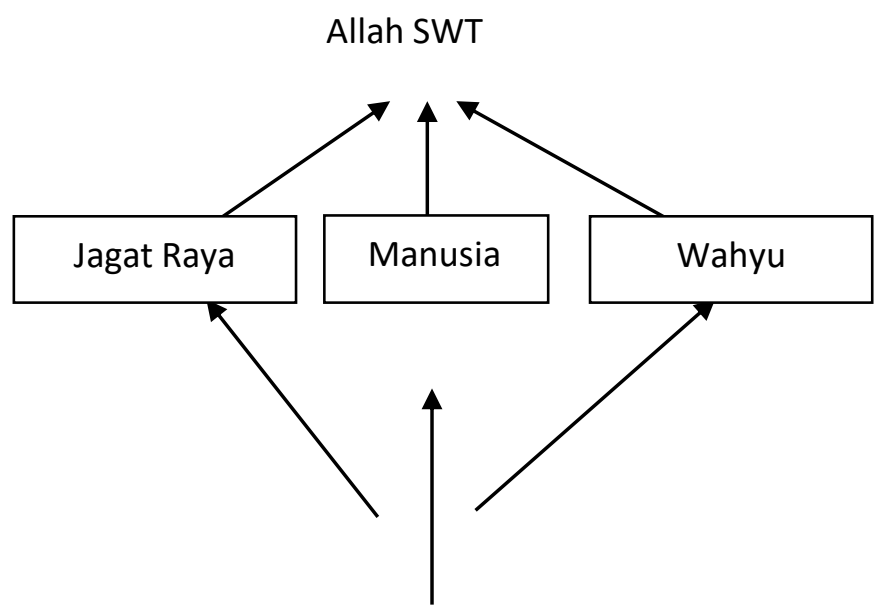

Tanda-tanda Allah

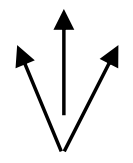

Manusia 
Sementara pandangan Al-Ghazali mengelompokan ilmu menjadi:

1. Ilmu Syar'iyyah, yaitu ilmu yang tidak diragukan lagi dampak positifnya.

2. Ilmu Ghayr Shar'iyyah, yaitu ilmu yang Kebenarannya relatif, dan tingkat validitasnya rendah.

Ilmu Shar'iyyah terdiri atas Al-qur'an dan Hadits, fiqh, ilmu bahasa (Arab), tafsir, ilmu hadits, dan ushul fiqh. Sedangkan ilmu Ghayr Shar'iyyah terdiri atas ilmu terpuji (karenanya bersifat fardu kifayah), seperti kedokteran, matematika, politik, dan hukum; kemudian ilmu mubah (netral), yang meliputi: sejarah, kebudayaan, dan sastra. Dan selanjutnya ilmu tercela, seperti ilmu sihir, ilmu magic, ilmu sulap, dan sebagian cabang filsafat.

\section{Sains Dunia Islam Masa Kini}

Dalam konteks Islam, tujuan pengembangan sains adalah untuk membangkitkan etos keilmuan di kalangan umat Islam, menuju masyarakat yang terbuka, kritis, dan kreatif.

Dunia Islam (kawasan Timur Tengah dan Asia Tenggara) merupakan kawasan bumi yang paling terbelakang (dalam bidang sains) di antara penganut ajaran agama-agama besar. Keadaan demikian disebabkan karena umat Islam tidak mampu memahami dengan 
sungguh-sungguh ajaran agamanya yang lebih dinamis dan lebih otentik.

Pembangunan ilmu sains yang rendah merupakan kegagalan yang memberi dampak kepada kemunduran negara-negara Islam pada hari ini. Akhirnya negara-negara Barat pasti menguasai bidang ekonomi dan intelek untuk jangka masa yang panjang. Walaupun kita telah melangkah ke abad 21, masih tidak nampak pergerakan atau perubahan yang signifikan di negara-negara Islam untuk mencapai kebudayaan yang berteraskan sains. Kegagalan kemajuan sains di kalangan negara-negara Islam juga berpuncak dari kegagalan pemerintah mempertahankan kedaulatan dan sumber negaranya, menyediakan keperluan asas kepada rakyat jelata dan menubuh kerajaan yang benar-benar mewakili rakyat. Jika kita lihat krisis di negara-negara Islam semuanya adalah berpuncak dari krisis politik. Tidak pernah berlaku dalam sejarah orang-orang Islam terjadi pemisahan kuasa politik dengan masyarakat. Hampir semua pemerintah negara Islam mengamalkan korupsi dan penindasan rakyatnya daripada mempertahankan sumber alam atau kedaulatan negara masing-masing dan mereka lebih cenderung tunduk kepada campur tangan luar.

\section{RANGKUMAN}


1.Hubungan antara IImu, agama dan budaya sangat berkaitan. Ilmu, dengan metodenya sendiri, mencari kebenaran tentang alam dan manusia. Agama, dengan karakternya sendiri mampu memberikan jawaban atas segala persoalan yang dipertanyakan manusia, baik tentang alam, manusia ataupun Tuhan yang tidak terjawab oleh ilmu. Dengan kekuatan akal (ilmu)nya, manusia menghampiri kebenaran. Agama tanpa ilmu dapat menyebabkan musyrik.

2. Dunia Islam (kawasan Timur Tengah dan Asia Tenggara) merupakan kawasan bumi yang paling terbelakang (dalam bidang sains) di antara penganut ajaran agamaagama besar. Keadaan demikian disebabkan karena umat Islam tidak mampu memahami dengan sungguhsungguh ajaran agamanya yang lebih dinamis dan lebih otentik.

\section{LATIHAN}

Analisislah perkembangan sains dunia Islam di Indonesia dan Negara lain yang anda ketahui! 


\section{BAB III}

\section{EPISTEMOLOGI ISLAM}

\section{A. PENDAHULUAN}

Sejak kedatangan Islam pada abad ke-13 M. hingga saat ini, fenomena pemahaman ke-Islaman umat Islam Indonesia masih ditandai oleh keadaan amat variatif. Kondisi pemahaman ke-Islaman serupa ini barangkali terjadi pula diberbagai negara lainnya. Kita tidak tahu persis apakah kondisi demikian itu merupakan sesuatu yang alami yang harus diterima sebagai suatu kenyataan untuk diambil hikmahnya, ataukah diperlukan adanya standar umum yang perlu diterapkan dan diberlakukan kepada berbagai paham keagamaan yang variatif itu, sehingga walaupun keadaannya amat bervariasi tetapi tidak keluar dari ajaran yang terkandung dalam al-Qur'an dan al-Sunnah serta sejalan dengan data-data historis.

Relasi agama dan ilmu tampaknya masih saja bercorak dikotomik. Selain itu, relasi ilmu satu dengan ilmu lainnya hingga kini juga masih tampak berjalan sendirisendiri. Tidak sedikit manusia modern yang meyakini bahwa sains dan agama merupakan entitas yang terpisah.Upaya untuk menyatukannya dianggap hanya akan mengurangi objektivitas sains dan sakralitas agama. Pada hakikatnya umat manusia belum bisa mengubah asumsi lama bahwa sains berangkat dari keragu-raguan (doubts), yang 
kemudian menggunakan metode ilmiah sebagai landasan dalam pencarian kebenaran, sedangkan agama berangkat dari sebuah keyakinan (belief), yang tidak dapat digugat.

Disinilah diperlukan jembatan epistemologis untuk mempertemukan kembali sains dan agama. Untuk memperjelas pemahaman mahasiswa tentang epistemologi Islam, akan dideskripsikan dalam bab ini mengenai hal itu dengan harapan bahwa mahasiswa mampu memahami arti dan definisi epistemologi, memahami aqpa yang menjadi sumber pengetahuan serta memahami kebenaran dalam epistemologi Islam.

\section{B. PENYAJIAN}

\section{Arti dan Definisi Epistemologi}

Epistemologi merupakan salah satu cabang filsafat yang membahas tentang hakikat pengetahuan manusia. Didalam lingkungan studi Islam, Epistemologi sering disandingkan dengan istilah pemikiran. Pemikiran berarti suatu entitas yang memperlihatkan proses menyerap, mengamati, mengingat bahkan memungkinkan manusia merefleksikan dunia obyektif ke dalam tataran konsep melalui proses abstraksi, analisis, sintesis, pemecahan dan hipotesis.

Menurut Harun Nasution, pengertian epistemologi ; episteme berarti pengetahuan dan epistemologi adalah ilmu yang membahas tentang apa pengetahuan dan bagaimana memperoleh pengetahuan. 
Selanjutnya, Furdyartanto memberikan pengertian epistemologi sebagai berikut; Epistemologi berarti : ilmu filsafat tentang pengetahuan atau pendek kata, filsafat pengetahuan.

Dari pengertian diatas Nampak bahwa epistemologi bersangkutan dengan masalah-masalah yang meliputi:

1) Filsafat yaitu sebagai ilmu berusaha mencari hakekat dan kebenaran pengetahuan.

2) Metode yaitu sebagai metode bertujuan mengantarkan manusia untuk memperoleh realitas kebenaran pengetahuan.

3) Sistem yaitu sebagai suatu sistem bertujuan memperoleh realitas kebenaran pengetahuan.

Persoalan pokok dalam epistemologi meliputi sumber-sumber pengetahuan, watak dari pengetahuan manusia, apakah valid atau tidak, dengan cara apa pengetahuan manusia didapat, serta syarat-syarat apa saja yang harus dipenuhi sehingga epistemology sampai pada problem hubungan metodologi dengan obyek dari ilmu pengetahuan.

\section{Sumber-Sumber IImu Pengetahuan}

\section{a. Wahyu}

sumber utama pengetahuan adalah wahyu atau alQuran sebagai sumber absolut yang berasal dari Tuhan semesta alam. Wahyu menempati posisi absolut karena 
bersumber dari yang absolut pula. Semua yang terkandung dalam wahyu adalah benar dan kebenarannnya tidak dapat dibantah manusia. Hampir setiap penilaian terhadap sesuatu senantiasa merujuk kepada wahyu tersebut. Wahyu yang menekankan ketiga sumber tersebut dan mengingatkan manusia tentang ketertinggalan dan kemunduran untuk memperoleh pengetahuan dan kebenaran tidak lain disebabkan oleh diri manusia itu sendiri yang lalai dan malas menggunakan semua potensi- potensi yang telah dianugerahkan kepada mereka atau pengetahuan itu tidak menghampiri manusia karena ada hijab (batas) yang menghalanginya.

Wahyu, baik berupa Al-Qur'an maupun hadits bersumber dari Allah SWT yang disampaikan kepada orang-orang pilihan-Nya (nabi/rasul). Adapun cara Allah dalam menurunkan wahyu kepada Nabi Muhammad SAW adalah sebagai berikut:

a. Malaikat memasukkan wahyu ke dalam hati Nabi Muhammad SAW.

b. Malaikat menampakkan dirinya kepada Nabi Muhammad SAW berupa seorang laki-laki.

c. Malaikat menampakkan dirinya kepada Nabi Muhammad SAW dalam rupanya yang asli.

d. Wahyu datang kepada Nabi Muhammad SAW seperti gemerincingnya lonceng. 
Wahyu yang berupa Al-Qur'an maupun hadits, memiliki karakteristik yang asli. Pengetahuan mengenai berbagai karakteristik ini dianggap sangat penting dalam kaitannya dengan pemahaman ajaran ajaran yang terkandung di dalamnya. Berikut ini adalah beberapa karakteristik wahyu:

a. Wahyu, baik berupa al-Qur'an maupun hadits, bersumber dari Tuhan. Pribadi Nabi SAW menyampaikan wahyu ini, memainkan peran yang sangat penting dalam menyampaikan makna wahyu tersebut. Seperti firman Allah dalam Q.S An-Najm [53]: 3-4 yang artinya : "Dan Tiadalah yang diucapkannya itu (Al-Quran) menurut kemauan hawa nafsunya. Ucapannya itu tiada lain hanyalah wahyu yang diwahyukan (kepadanya)."

b. Wahyu, baik berupa Al-Qur'an maupun hadits, merupakan perintah yang berlaku umum atas seluruh umat manusia, tanpa mengenal ruang dan waktu, baik perintah itu diungkapkan dalam bentuk umum maupun khusus.

c. Wahyu itu berupa nash-nash yang berbahasa Arab dengan gaya ungkap bahasa yang berlaku. Orang Arab Memiliki gramatika khas dalam bahasa mereka, baik dari segi indikasi lafal terhadap maknanya, dari segi pemakaian makna yang tidak terkandung pada lafalnya maupun dari segi kekayaan sastranya. Wahyu ini menggunakan bahasa arab dengan kaidahnya yang paling tinggi, sehingga Al- 
Qur'an mencapai tingkat yang tidak dapat dijangkau manusia.

d. Apa yang dibawa oleh wahyu itu tidak ada yang bertentangan dengan akal, bahkan ia sejalan dengan prinsip prinsip akal.

e. Wahyu itu merupakan satu kesatuan yang lengkap, tidak terpisah pisah. Di antara tanda kesatuannya adalah penafsiran satu bagian dengan bagian yang lainnya saling berhubungan.

f. Wahyu itu menegakkan hukum menurut kategori perbuatan manusia, baik berupa perintah maupun larangan. Keduanya berkaitan dengan ujaran yang sifatnya langsung terkait dengan jenis perbuatan tersebut.

g. Sesungguhnya wahyu, yang berupa Al-Qur'an dan hadits, turun secara berangsur angsur dalam rentang waktu yang cukup panjang. Turunnya sesuai dengan keperluan dan kasus yang terjadi pada zaman dan tempat dimana ia diturunkan.

Di kalangan kaum muslimin ada dua tipe pemikiran dalam memahami wahyu itu sebagai sumber. Pertama, sebagai sumber ilmu pengetahuan ilmiyah dan kedua, sebagai sumber petunjuk. Jalaluddin al-Suyuthi, Muhammad Shadiq al-Rafi'i, Abd al-Razzaq al-Naufal dan Maurice Bucaille, mereka tergolong kedalam kelompok yang pertama sedangkan Ibn Ishak al-Syathibi dan Quraish Shihab termasuk kelompok yang kedua. Mahdi Ghulsyani 
memilih berada diantara kedua kelompok tersebut, ia menekankan wahyu itu sebagai petunjuk bagi manusia yang mengandung ilmu pengetahuan dan manusia itu diperintahkan untuk senantiasa menggunakan indra, akal dan hatinya untuk menggali pengetahuan dari alam ini atas bimbingan wahyu itu sendiri.

\section{b.Akal}

Sumber pengetahuan yang lain adalah akal yang mempunyai fungsi sangat besar untuk memperoleh ilmu pengetahuan. Dari segi bahasa kata 'aql berarti "ikatan, batasan, atau menahan", di samping arti sebagai daya berpikir. Menurut Asy-Syafi'i dan Abi 'Abdillah, dari Mujahid bahwa akal adalah alat untuk membedakan baikburuk, benar-salah (al-'aql alat at-tamyiz). Juga dapat diambil pendapat bahwa akal adalah sesuatu yang dengannya diketahui yang benar (al-haq) dari yang salah (al-batil).

Akal memiliki posisi sangat tinggi dalam Islam, ia berpotensi sebagai alat untuk berfikir, memahami dan mengambil kesimpulan, khususnya dikalangan para filosof dibagi kepada dua yakni aktif dan teoritis dengan fungsinya masing-masing. Akal aktif berkaitan dengan etika, sedangkan yang pokok akal teoritis merupakan fakultas pemahaman.

Manusia dibedakan dari hewan oleh kecakapan mental yang luar biasa, yang tidak dimiliki oleh hewan 
yakni akal. Akal mempunyai kemampuan bertanya secara kritis. Kelebihan yang paling istimewa dari akal terletak pada kecakapan atau kemampuannya untuk menangkap kuiditas atau esensi dari sesuatu yang diamati atau dipahaminya.

\section{c.Alat Indera}

Sebagai sumber atau ada yang mengatakan alat pengetahuan, indra tentu sangat penting. Begitu pentingnya indra sehingga oleh aliran filsafat tertentu, seperti empirisme, indra dipandang sebagai satu-satunya sumber pengetahuan. Indra adalah sumber awal mengenal alam sekeliling kita. Bahkan satu riwayat menyatakan : "apabila seorang manusia kehilangan salah satu indranya, maka ia telah kehilangan setengah ilmu". Melalui mata manusia menangkap hal-hal yang tampak apakah bentuk, keberadaan, sifat atau karakteristik benda-benda yang ada di dunia. Melalui telinga dapat mendengar suara. Demikian juga dengan indra perasa, kita bisa mengenal dimensi yang lain lagi dari objek-objek dunia yaitu rasa, (masam, manis, asam, pahit dan lainlain) yang tentunya tidak dapat dilihat dan didengar oleh mata dan telinga .Indra peraba untuk memegang. Tak kalah pentingnya juga indra penciuman yang dapat menyerap aspek lain dari objek-objek fisik yaitu bau Setelah melihat fungsi indra sangat besar pengaruhnya untuk mendapatkan pengetahuan. Persoalan sekarang, 
cukupkah indra memenuhi kebutuhan akan ilmu sebagai pengetahuan tentang sesuatu sebagaimana adanya? ternyata indra itu terbatas. Banyak dorongan dan perintah bagi kaum muslimin dalam Alquran untuk mengadakan pengamatan (observasi) dengan indera juga penalaran dalam memahami alam.

Panca Indera sebagai sumber pengetahuan, sepintas lalu, tampaknya telah mencukupi kebutuhan kita akan pengetahuan, karena melalui panca indera, kita bisa mengenal lima dimensi, dari sebuah benda yang kita amati. Persepsi indera telah cukup memadai untuk menghindari diri dari banyak bahaya yang sangat diperlukan untuk kelangsungan hidup. Namun, pertanyaannya sekarang adalah apakah panca indera saja sudah cukup memasok kebutuhan kita akan ilmu sebagai pengetahuan tentang sesuatu sebagaimana adanya?. Apakah misalnya penglihatan kita telah mampu memberi kita pengetahuan tentang sebuah benda, katakanlah langit, bulan atau bintang ?. Misalnya, kita bisa mengatakan bahwa langit itu biru, bulan itu pipih seperti piring, atau bintang itu kecil. Namun, Apakah penglihatan kita melaporkan benda-benda itu sendiri sebagaimana adanya, atau hanya semata-mata kesan yang terserap oleh mata kita belaka? Apakah kesan indera kita itu sama dengan kenyataan (sebagaimana adanya) ?. Ternyata, dengan pertanyaan yang sedikit kritis terhadap pengetahuan indera, kita tahu bahwa kesan indera itu 
tidaklah sesuai dengan keadaan benda itu sebagaimana adanya, bahwa kita menduga langit itu berwarna biru, padahal langit itu sendiri tidak jelas definisinya.dan bagaimana bentuknya yang sebenarnya.

Indera kita mengesankan bahwa langit itu seperti kubah besar yang dapat dilihat dari dalam dengan bintang-bintang dan bulan menempel disana, tentu saja itu tidak sebagaimana adanya karena yang kita sebut langit : adalah ruang angkasa yang tak terukur jauhnya, yang tidak dapat ditangkap oleh indera penglihatan kita. Berdasarkan penglihatan, kita akan menduga bahwa bintang yang berkerlap-kerlip di langit ada disana pada saat kita melihatnya, padahal, menurut penyelidikan ilmiah, bisa saja cahaya bintang yang kita lihat sekarang telah sirna karena bisa jadi cahaya bintang yang kita lihat sekarang adalah cahaya yang berjarak jauh, yang membutuhkan jutaan tahun untuk merambat sampai ke mata kita, jadi disini menjadi jelas, bahwa kesan yang kita tangkap jauh berbeda dengan keadaan sebenarnya.

Dari contoh diatas kita menjadi sadar betapa indera kita yang sepintas, telah (dirasa) cukup memberi kita pengetahuan (informasi) tentang benda-benda inderawi. Ternyata, kita tidak cukup memadai untuk mengetahui sesuatu sebagaimana adanya, jika hanya mengandalkan panca indera saja. oleh karena itu, kita membutuhkan bantuan alat atau sumber lain untuk pengetahuan kita, 
dalam rangka untuk mengetahui tentang sesuatu sebagaimana adanya, yakni akal.

\section{d.Hati (Intuisi)}

Ketika akal tidak mampu memahami "Wilayah kehidupan emosional manusia" hati kemudian dapat memahaminya, hati(intuisi) yang terlatih akan dapat memahami perasaan seseorang. Ketika akal hanya berkutat, pada tataran kesadaran, hati bisa menerobos ke alam ketidaksadaran atau alam gaib sehingga mampu memahami pengalaman-pengalaman non inderawi termasuk pengalaman mistik atau religius. la bahkan bisa berkomunikasi dengan bahasa hati dengan makhlukmakhluk gaib, seperti malaikat, jin bahkan Tuhan sendiri, seperti yang dialami oleh para Nabi dan Rasul.

Hati juga mempunyai kemampuan untuk mengenal objeknya secara lebih akrab dan langsung. Pengetahuan intuitif adalah pengetahuan eksperiental atau pengetahuan yang didasarkan pada pengalaman. la mengerti "manis" bukan dari kata orang ataupun melalui bacaan, melainkan melalui mencicipinya. la, misalnya mengerti "cinta" bukan melalui mulut orang atau bacaan dan teori-teori cinta yang sering jauh berbeda dengan yang dialami, melainkan memahaminya dengan betulbetul jatuh cinta. Tidak bisa terbayangkan indahnya "mencintai" bagi akal, tetapi hati sangat memahaminya, sekalipun mungkin ia tidak bisa mengungkapkannya 
lewat kata-kata, karena mengungkapkan perasaan cinta mengharuskan kita menggunakan "peraturan" bahasa yang bersifat rasional dan logis.

Selain itu, pengetahuan hati juga disebut "presensial" karena objeknya dipandang hadir dalam diri atau jiwa seseorang. Tidak ada lagi jurang yang memisahkan seseorang dari objek yang ditelitinya karena ia telah bersatu dan telah hadir pada dirinya. Dari sinilah kita dapat mengerti mengapa banyak para sufi yang telah merasa bersatu dengan kekasihnya yaitu Tuhan.

Seseorang yang sedang terpusat pemikirannya pada suatu masalah tiba-tiba saja menemukan jawaban atas permasalahan tersebut. Tanpa melalui proses berpikir yang berliku-liku tiba-tiba saja dia sudah sampai di situ. Jawaban atas permasalahan yang sedang dipikirkannya muncul di benaknya bagaikan kebenaran yang membukakan pintu. Atau bisa juga, intuisi ini bekerja dalam keadaan yang tidak sepenuhnya sadar, artinya jawaban atas suatu permasalahan ditemukan tidak pada waktu orang tersebut secara sadar sedang menggelutinya. Suatu masalah yang sedang kita pikirkan, yang kemudian kita tunda karena menemui jalan buntu, tiba-tiba saja muncul di benak kita yang lengkap dengan jawabannya, dan kita merasa yakin bahwa memang itulah jawaban yang kita cari namun kita tidak bisa menjelaskan bagaimana caranya kita sampai ke sana. 
Intuisi bersifat personal dan tidak bisa diandalkan sebagai dasar untuk menyusun pengetahuan secara teratur. Namun, Pengetahuan intuitif dapat dipergunakan sebagai hipotesis bagi analisis selanjutnya dalam menentukan benar tidaknya pernyataan yang dikemukakannya. Kegiatan intuitif dan analitik bisa bekerja saling membantu dalam menemukan kebenaran.

\section{Kebenaran Dalam Epistemologi Islam}

Pandangan Islam akan kebenaran merujuk kepada landasan keimanan dan keyakinan terhadap keadilan yang bersumber pada Al-Qur'an. Sebagaimana yang diutarakan oleh fazrur rahman bahwa semangat dasar dari Al-qur'an adalah semangat moral, ide-ide keadilan social dan ekonomi. Hokum moral adalah abadi, ia adalah "perintah Allah". Manusia tak dapat membuat dan memusnahkan hokum moral: ia harus menyerahkan diri kepadanya. Pernyataan ini dinamakan Islam dan Implementasinya dalam kehidupan di sebut Ibadah atau pengabdian kepada Allah. Tetapi hokum moral dan nilainilai spiritual, untuk bisa dilaksanakan haruslah diketahui.

Dalam kajian epistemologi Islam dijumpai beberapa teori tentang kebenaran :

a.Teori Korespondensi

Menurut teori ini suatu posisi atau pengertian itu benar adalah apabila terdapat suatu fakta bersesuaian, yang 
beralasan dengan realistis, yang serasi dengan situasi aktual, maka kebenaran adalah sesuai dengan fakta dan sesuatu yang selaras dengan situasi akal.

b. Teori Konsistensi

Menurut teori ini kebenaran tidak dibentuk atas hubungan antara putusan (judgement) dengan suatu yang lain yaitu fakta atau realitas, tetapi atas hubungan antara putusan-putusan itu sendiri. Dengan kata lain, kebenaran ditegakkan atas hubungan antara putusanputusan yang baik dengan putusan lainnya yang telah kita ketahui dan diakui benar terlebih dahulu, jadi sesuatu itu benar, hubungan itu saling berhubungan dengan kebenaran sebelumnya

c. Teori Prakmatis

Teori ini mengemukakan benar tidaknya suatu ucapan, dalil atau semata-mata tergantung kepada berfaedah tidaknya ucapan, dalil atau teori tersebut bagi manusia untuk berfaedah dalam kehidupannya.

Sedangkan kriteria kebenaran yang harus dipenuhi antara lain adalah:

a. Berdasarkan fakta

b. Bebas dari prasangka

c. Menggunakan prinsip-prinsip analisis

d. Menggunakan hipotesa 
e. Menggunaka ukuran yang objektif

f. Menggunakan teknik kuantifikasi.

Setelah semua kriteria telah dipenuhi, maka langkah berikutnya, yaitu:

a. Memilih dan mendefinisikan masalah

b. Survey terhadap data yang tersedia

c. Memformulasikan hipotesa

d. Membangun kerangka analisa

e. Mengumpulkan data primer

f. Mengolah, menganalisa serta membuat interpretasi

g. Membuat generalisasi dan kesimpulan

h. Membuat laporan.

\section{RANGKUMAN}

1. Epistemologi merupakan salah satu cabang filsafat yang membahas tentang hakikat pengetahuan manusia. Didalam lingkungan studi Islam.

2. Sumber-Sumber IImu Pengetahuan ada empat, meliputi wahyu, akal, alat indera dan hati (intuisi).

3. Dalam kajian epistemologi Islam dijumpai beberapa teori tentang kebenaran, yaitu teori korespondensi, teori konsistensi dan teori prakmatis.

\section{LATIHAN}

1. Jelaskan menurut pendapat anda tentang memahami epistemology sebelum melakukan penelitian! 
2. Deskripsikan menurut analisa anda, Mengapa wahyu merupakan sumber epistemologi yang utama! 


\section{BAB IV}

\section{PENDEKATAN DALAM STUDI ISLAM}

\section{A. PENDAHULUAN}

Dalam memecahkan berbagai masalah yang dihadapi umat manusia, diperlukan peran aktif keterlibatan agama dalam penyelesaiannya. Agama tidak boleh hanya sekedar menjadi lambang kesalehan namun mampu menunjukkkan cara-cara yang paling efektif dalam memecahkan masalah secara konsepsional.

Hal ini akan terjawab oleh agama manakala pemahaman agama yang selama ini banyak menggunakan pendekatan teologis dilengkapi dengan pemahaman agama yang menggunakan pendekatan lain, yang secara operasional konseptual, dapat memberikan jawaban terhadap masalah yang timbul.

Untuk mengkaji Islam diperlukan pendekatan yang mampu menganalisis secara objektif. Hal demikian perlu dilakukan, karena pendekatan tersebut kehadiran agama secara fungsional dapat dirasakan oleh penganutnya. Pendekatan merupakan cara pandang atau paradigma yang terdapat dalam suatu bidang ilmu yang selanjutnya digunakan dalam memahami agama.

M. Amin abdullah menyarankan agar studi agama di Indonesia dikembangkan secara komprehensif, multidisipliner, interdisipliner dengan menggunakan 
metodologis yang bersifat historis-kritis untuk melengkapi penggunaan metodologi yang bersifat doktriner-normatif.

Untuk memberikan bekal kepada mahasiswa tentang metodologi studi Islam, Berbagai pendekatan akan dibahas dalam bab ini yang meliputi pendekatan teologis normatif, antropologis, sosiologis, psikologis, historis, kebudayaan dan pendekatan filosofis. Dari uraian ini, mahasiswa diharapkan mapu memahami dan mendeskripsikan berbagai pendekatan dalam studi Islam.

\section{B. PENYAJIAN}

\section{Pendekatan Normatif}

Pendekatan normatif adalah studi Islam yang memandang masalah dari sudut legal formal dan atau normatifnya. Maksud legal formal adalah hubungannya dengan halal-haram, boleh atau tidak,dan sejenisnya. Sementara normatifnya adalah seluruh ajaran yang terkandung dalam nash. Pendekatan ini menekankan pada bentuk formal atau symbol-simbol keagamaan yang masing-masing mengklaim dirinya paling benar, sedangkan yang lain salah. Dengan demikian pendekatan normatif mempunyai cakupan yang sangat luas. Sebab seluruh pendekatan yang digunakan oleh ahli usul fiqih (Usuliyah), ahli hukum Islam (Fuqaha),ahli tafsir(mufassirin) yang berusaha menggali aspek legal formal dan ajaran Islam dari sumbernya adalah termasuk pendekatan normatif. 
Sisi lain dengan pendekatan normatif adalah bahwa secara umum ada dua teori yang dapat digunakan dengan pendekatan normatif-teologis. Pertama,ada hal-hal yang untuk mengetahui kebenarannya dapat dibuktikan secara empirik dan eksperimental. Kedua, ada hal-hal yang sulit dibuktikan secara empiris dan eksperimental. Untuk ha-hal yang dapat dibuktikan secara empirik biasanya disebut masalah yang berhubungan ra'yi (penalaran). Sedangkan masalah-masalah yang tidak berhubungan dengan empirik (ghaib) biasanya diusahakan pembuktiannya dengan mendahulukan kepercayaan. Hanya saja cukup sulit untuk menentukan hal-hal apa saja yang masuk klasifikasi empirik dan mana yang tidak terjadi perbedaan pendapat dikalangan para ahli. Maka sikap yang perlu dilakukan dengan pendekatan normatif adalah sikap kritis.

Ada beberapa teori popular yang dapat digunakan dengan pendelatan normatif, disamping teori-teori yang digunakan oleh parafuqaha', usuliyin, muhadditin, dan mufassirin, diantaranya adalah teori teologisfolosofis, yaitu pendekatan memahami al-Qur'an dengan cara mengintrepretasikannya secara logis-filosofis,yakni mencari nilai-nilai objektif dari subjektif al-Qur'an. Selanjutnya teori lain yakni normatif-sosiologis atau sosiologis teologis yang ditawarkan oleh Asghar Ali Engerineer dan Tahnir al-Haddad,yakni dalam memahami nash (al-Qur'an dan sunnah Nabi Muhammad Saw. Ada pemisahan antara nash normative dengan nash sosiologis. 
Nash normative adalah nash yang tidak tergantung pada konteks. Sementara nash sosiologis adalah nash yang pemahamannya harus disesuaikan dengan konteks, waktu,tempat,dan konteks lainnya.

Dalam memahami nash, khususnya al-Qur'an, Muhammad Izzat darwaz mengatakan bahwa al-Qur'an berisi dua pokok :

1. Prinsip fundamental (usul)

2. Alat/penghubung untuk mencapai prinsip-prinsip fundamental tersebut.

Prinsip-prinsip tersebut penting karena didalamnya mengandung tujuan wahyu dan dakwah Nabi. Hal-hal yang termasuk prinsip adalah menyembah Allah dan harus menyediakan kode etik (norma) yang lengkap (komprehensif) tentang tindakan-tindakan (syariah). Yang lainnya seperti janji Allah akan membalas perbuatan baik di akhirat berupa surga dan akan menyiksa orang-orang yang dzalim atau jahat dengan hukuman neraka, sejarah Nabi dan semacamnya adalah penghubung.

Dalam kajian yang lainnya yakni dalam sisi teologis sangat erat juga kaitannya dengan pendekatan normatif yaitu suatu pendekatan yang memandang agama dari segi ajarannya yang pokok dan asli dari Tuhan yang didalamnya belum terdapat penalaran pemikiran manusia. Dalam pendekatan teologis agama dilihat sebagai suatu kebenaran mutlak dari Tuhan,tidak ada kekurangan 
sedikitpun dan tampak bersikap ideal. Dalam kaitan ini agama tampil sangat prima dengan seperangkat cirinya yang khas. Untuk agama Islam,secara normatif pasti benar,menjunjung nilai-nilai luhur yang diajarkan dalam kitab suci Al-Qur'an dan Hadist Nabi Saw.

Untuk bidang sosial misalnya dalam ajarannya agama tampil menawarkan nilai-nilai kemanusiaan, kebersamaan, kesetiakawanan, tolong menolong,tenggang rasa,persamaan derajat dan sebagainya. Untuk bidang ekonomi agama tampil menawarkan keadilan, kebersamaan, kejujuran dan saling menguntungkan. Untuk bidang ilmu pengetahuan, agama tampil mendorong pemeluknya agar memiliki ilmu setinggitingginya, menguasai ketrampilan, keahlian dan sebagainya. Demikian pula untuk bidang kesehatan lingkungan hidup, kebudayaan politik, dan sebagainya agama tampil ideal dan yang dibangun berdasarkan dalildalil yang terdapat dalam ajaran agama yang bersangkutan.

\section{Pendekatan Antropologis}

Antropologi berasal dari kata antropos dan logis, yang berarti manusia dan ilmu, antropologi merupakan istilah yang digunakan dalam cabang keilmuan yang membicarakan manusia. Dalam kamus Besar Bahasa Indonesia, Antropologi disebut sebagai IImu tentang manusia, khususnya tenrang asal-usul, aneka warna 
bentuk fisik, adat istiadat dan kepercayaannya pada masa lampau.

Antropologi atau "IImu tentang manusia" merupakan suatu istilah yang pada awalnya mempunyai makna yang lain, yaitu "ilmu tentang ciriciri tubuh manusia". Dalam fase ketiga perkembangan antropologi, istilah ini terutama mulai dipakai di Inggris dan Amerika dengan arti yang sama seperti etnologi pada awalnya. Di Inggris, istilah antropologi kemudian mengubah istilah etnologi.

Dari uraian yang disebutkan di atas dapat disimpulkan bahwa Antropologi ialah suatu ilmu yang mempelajari tentang manusia baik dalam hal-hal yang berkaitan dengan aspek fisik yakni: warna kulit, bentuk rambut, bentuk muka, bentuk hidung, tinggi badan maupun dalam hal-hal yang berkaitan dengan kehidupan sosialnya.

Penelitian agama dengan menggunakan pendekatan antropologi pada dasarnya dengan menggunakan teknik participant observaticm dengan melakukan berbagai interview.

Pendekatan antropologi budaya dan sosial dapat digunakan dalam upaya mengkaji fenomenafenomena keagamaan tersebut dengan rujuan untuk lebih dapat memahami perilaku umat Islam dan dalam rangka pembangunan kehidupan beragama umat Islam itu sendiri. Namun dalam penerapannya 
perlu menyelaraskan pendekatan antropologi ini dengan nilai-nilai yang dikandung Islam.

\section{Pendekatan Sosiologis}

Secara etimologi, kata sosiologi berasal dari bahasa latin yang terdiri dari kata Socius yang berarti teman dan Logos yang berarti berkata atau teman bicara. Jadi sosiologi artinya berbicara tentang manusia yang berteman atau bermasyarakat. Sedangkan secara terminologi maka sosiologi mengandung pengertian sebagai berikut:

Sosiologi merupakan suatu disiplin ilmu yang luas dan mencakup berbagai hal, dan ada banyak jenis sosiologi yang mempelajari sesuatu yang berbeda dengan tujuan yang berbeda-beda pula.

Sosiologi rnerupakan ilmu pengetahuan yang mempelajari masyarakat sebagai keseluruhan, yakni hubungan antara manusia dengan manusia, manusia dengan kelompok, kelompok dengan kelompok, baik formal maupun non formal, baik statis maupun dinamis.

Sosiologi adalah ilmu yang mempelajari hidup bersama dalam masyarakat dan menyelidiki ikatan-ikatan antara manusia yang menguasai hidupnya itu. Soerjono Soekanto mengartikan sosiologi sebagai suatu ilmu pengetahuan yang membatasi diri terhadap persoalan penilaian.

Dari definisi diatas terlihat bahwa sosiologi adalah ilmu yang menggambarkan tentang keadaan masyarakat 
lengkap dengan struktur, lapisan serta berbagai gejala sosial lainnya yang saling berkaitan.

Selanjutnya, sosiologi dapat digunakan sebagai salah satu pendekatan dalam memahami agama. Hal demikian dapat dimengerti, karena banyak bidang kajian agama yang baru dapat dipahami secara proporsional dan tepat apabila menggunakan jasa bantuan dan ilmu sosiologi.

Suatu penelitian yang didasarkan pada metode ini tidak hanya melihat perilaku manusia dari yang tampak saja,terapi secaraeksplisit dan implisir. Selanjutnya ada beberapa pendekatan lain yang digunaka.n para sarjana dalam penelitiannya terhadap gejala-gejala sqsial,yaltu; peodekaran struktural fungsional, pendekatan Marxian (pendekaran konflik, dan pendekatan interaksionalisme simbolis.

Pendekatan Interaksionalisme-simbolis, bertolak dari interaksi sosial pada tingkat minimal. Pendekatan ini disebut dengan pendekatan mikro karena pendekatan ini melihat manusia pada hubungan yang lebih sederhana. Tokoh-tokoh yang berperan mengembangkan pendekaran ini antara lain John Locke, Jhon Horton Cooley, Robert Park dan lainnya.

Agama (religion) dalam kajian sosiologi termasuk ke dalam sub kajian yang banyak mendapat sorotan dari para sosiolog karena dianggap menarik. Berawal dari seperangkat kepercayaan, perlambang dan praktik 
yang didasarkan atas ide tentang yang sakral (baud on the idea of sacred), agama mampu menciptakan polapola yang baik dan teratur dalam kehidupan suatu masyarakat dan menciptakan sebuah komunitas sosiorelijius yang dalam tingkah lakunya dipengaruhi oleh keyakinan tersebut.

Dalam sebuah masyarakat, biasanya agama merupakan salah satu struktur institusional penting yang melengkapi keseluruhan system sosial, akan tetapi masalah agama tentunya berbeda dengan masalah politik dan hukum yang berkaitan dengan pengendalian kekuasaan, berbeda dengan lembaga ekonomi yang berkaitan dengan kerja sama dalam menghasilkan uang dan barang, dan juga berbeda dengan lembaga keluarga yang mengatur hubungan antar jenis kelamin, antar generasi, ataupun hubungan lainnya dalam sebuah keluarga.

Fokus pada pendekatan sosiologi dalam studi Islam adalah memahami Islam sebagai fenomena yang menyejarah dalam sosial dan budaya. Perlu dipahami bahwa ragam dan corak keislaman sesungguhnya tidak terlepas dari dinamika pemahaman umat Islam yang berbeda - beda tentang ajaran Islam yang berdasarkan setting sosial dan budaya yang melatar belakangi serta yang dihadapi umat Islam itu sendiri.

Menegaskan bahwa fenomena keberagamaan dalam hal ini Islam, baik di kawasan Eropa, Amerika, 
Timur Tengah dan bahkan Asia Tenggara, mempunyai karakteristik sendiri - sendiri berdasarkan fenomena sosial dan budaya di mana Islam berkembang bersama masyarakat.

Dalam memahami kitab al-Qur'an kita tidak lepas dari konteks historisnya, dan tak berhenti pada teksnya saja. Teks harus diinterpretasikan berdasarkan konteks dari turunnya teks atau nashnya. Di sinilah sesungguhnya letak pertautan antara teks dengan konteks.

Melepaskan teks dari konteks historisnya mengakibatkan kita berhadapan dengan teks yang kosong, hingga berupa kata - kata indah dan manis kemudian dimitoskan, sehingga tidak sepenuhnya dapat menjelaskan realitas kebenaran yang hendak di ungkapkan oleh teks atau Nash itu sendiri. Di sinilah urgensinya teks atau Nash suci dengan fungsi utama ajaran Islam sebagai pembimbing manusia menuju kebahagiaan hidup di dunia dan di akhirat.

Dalam usaha menghayati teks itu tadi dimungkinkan terjadinya interelasi teks, sehingga dapat menyatu dan memperkuat suara hati nuraninya, dan berfungsi kontrol internal dan otomatis untuk mendorong dan memperkuat keshalihan sosial seseorang. Ketika teks itu diturunkan dengan keadaan sosial dan budaya sesuai kondisi waktu itu. Teks atau Nash yang kita baca atau kita pahami lalu kita kaitkan 
dengan sejarah atau konteks bagaimana kehidupan pada waktu itu lalu kita dapat mengambil kesimpulan dan dapat mengembangkan atau mengaplikasikan dalam kehidupan sekarang.

Dalam menghadapi persoalan tidak bolehnya wanita menjadi kepala negara. berangkat dari hadis nabi yang diriwayatkan oleh Bukhari, Ahmad Nasa'i dan Tirmidzi " tidak akan bahagia apabila suatu kaum yang mengangkat wanita sebagai pimpinan mereka ". Hadis ini jika dipahami secara harfiah jelas bahwa seorang wanita itu dilarang untuk menjadi kepala negara. tetapi jika dipahami secara konteks asbab alwurud-nya, maka sebenarnya larangan itu hanya bisa terjadi bila wanita sendirian menentukan urusan bangsanya. Pada waktu itu kata Dr. Kamal jadah dalam Wadifah al-Mar'ah di nazar al-Islam, binti kisrah telah diangkat menjadi ratu / pemimpin Persia. Sudah bahwa sebagian besar raja raja pada saat itu kekuasaanya hanya di tangannya sendiri. Hanya dia sendiri yang menetapkan urusan rakyat dan negerinya, ketapannya tidak boleh digugat.

Berdasarkan hadist tersebut dapat diambil kesimpulan bahwa mempelajari agama Islam tidak hanya menggunakan satu ilmu saja melainkan dengan mengkaitkan ilmu - ilmu yang relevan agar tujuan Islam sesuai dengan tujuannya. Hal ini dapat ditarik kesimpulan, ketika kita ingin memahami suatu hadis bukan hanya sekedar berfikir saja melainkan juga 
melihat konteks sosial dan sejarahnya. Memahami arti sama halnya kita berfilsafat akan kebenaran makna tersebut. Ketika berfilsafat atau berfikir kita juga harus menggunakan pendekatan ilmu - ilmu sosial dan ilmu sejarah. Apa sebab turunnya hadis tersebut, bagaimana keadaan sosial tersebut. Lalu kita bisa menjawab pertanyaan tersebut kita bisa menggunakan ilmu sejarah.

\section{Pendekatan Filosofis}

Kata filsafat diambil dari bahasa arab "falsafah" atau filsafat. Orang arab mengambil dari bahasa yunani philos dan shopia. Philos artinya cinta dalam arti seluas - luasnya, ingin dan karena ingin itu selalu berusaha mencapai yang diingininya. Sedangkan shopia berarti "kebijaksanaan", bijaksana berarti "pandai", yakni mengerti dengan mendalam. Dengan demikian dari segi bahasa kata filsafat bisa diartikan ingin mengerti dengan mendalam atau cinta dengan kebijaksanaan.

Dalam Kamus Umum Bahasa Indonesia, Poerwadarminta mengartikan filsafat sebagai pengetahuan dan penyelidikan dengan akal budi mengenai sebab-sebab, asas-asas, hukum dan sebagainya terhadap segala yang ada di alam semesta ataupun mengenai kebenaran dan arti "adanya" sesuatu.

Pengertian filsafat yang umumnya digunakan adalah pendapat yang dikemukakan Sidi Gazalba. Menurutnya 
filsafat adalah berpikir secara mendalam, sitemik, radikal dan universal dalam rangka mencari kebenaran, inti, hikmah atau hakikat mengenai segala sesuatu yang ada. Filsafat mencari sesuatu yang mendasar, asas, dan inti yang terdapat di balik yang bersifat lahiriah.

Menurut Harun Nasution bahwa definisi filsafat itu bermacam - macam antara lain sebagai berikut :

1. Pengetahuan hikmah

2. Pengetahuan prinsip atau dasar - dasar

3. Mencari kebenaran

4. Membahas dari apa yang dibahas

Namun dapat dikatakan bahwa intisari filsafat adalah berfikir menurut tata tertib ( logika ) dengan bebas ( tidak terikat pada tradisi, dogma dan sebagainya ) dan sedalam dalamnya sehingga sampai ke dasar - dasar persoalan. Menurut Muhaimin , filsafat mengandung pengertian sebagai berikut :

1. Sebagai aktivitas pikir murni atau kegiatan akal pikir manusia dalam usaha untuk mengerti secara mendalam tentang segala sesuatu

2. Suatu produk berfikir murni, jadi filsafat merupakan suatu "wujud" ilmu sebagai hasil pemikiran dan penyelidikan.

Dari beberapa pengertian di atas, dapat diambil kesimpulan bahwa filsafat adalah berfikir secara bebas menurut tata tertib dengan tujuan untuk mengerti 
secara mendalam tentang segala sesuatu dan hasil berfikir tersebut sebagai ilmu pengetahuan baru.

Filsafat merupakan induk dari segala ilmu yang terdiri dari gabungan ilmu-ilmu khusus. Dalam perkembangan ilmu-ilmu khusus satu demi satu memisahkan diri dari induknya yakni filsafat.

Filsafat sebagai pendekatan keilmuan setidaknya ditandai antara lain dengan tiga ciri:

(1) Kajian, telaah dan penelitian filsafat selalu terarah kepada pencarian atau perumusan ide-ide dasar atau gagasan yang bersifat mendasarfundamental (fundamental ideas) terhadap objek persoalan yang dikaji. Ide atau pemikiran fundamental biasanya diterjemahkan dengan istilah teknis kefilsafatan sebagai "al-falsafatu alula", substansi, hakekat atau esensi. Pemikiran fundamental biasanya bersifat umum (general), mendasar dan abstrak.

(2) Pengenalan, pendalaman persoalan-persoalan dan isu-isu fundamental dapat membentuk cara berpikir kritis (critical thought).

(3) Kajian dan pendekatan filsafat yang bersifat seperti dua hal diatas, akan dapat membentuk mentalitas, cara berpikir dan kepribadian yang mengutamakan kebebasan intelektual (intellectual freedom), sekaligus mempunyai sikap toleran terhadap berbagai pandangan dan kepercayaan yang 
berbeda serta terbebas dari dogmatisme dan fanatisme.

Mengkaji Islam secara filosofis, akan menjadikan segala sesuatu disandarkan kepada konteks baik itu berupa kebaiksan sosial, local wisdom, social impact, rasionalitas dan lain-lain. la juga akan bersandar pada analisa rasio manusia, yang akan bersifat relatif. Kegiatan berfilsafat menurut Louis $\mathrm{O}$. Kattsoff adalah kegiatan berpikir secara:

1. Mendalam: dilakukan sedemikian rupa hingga dicari sampai ke batas akal tidak sanggup lagi.

2. Radikal: sampai ke akar-akarnya sehingga tidak ada lagi yang tersisa.

3. Sistematik: dilakukan secara teratur dengan menggunakan metode berpikir tertentu. 4. Universal: tidak dibatasi hanya pada satu kepentingan kelompok tertentu, tetapi menyeluruh.

Filsafat dalam segala usahanya untuk mengetahui berbagai hakikat dari segala sesuatu, begitu pula ketika ia dipakai dalam mengkaji Islam, tidak selalu mencapai hasil yang maksimal, yang terpenting adalah upaya (memanfaatkan hasil 
usaha), yang akan membuat suatu perubahan ke arah yang lebih baik lagi atau kemajuan.

Manfaat yang bisa didapat ketika seseorang menggunakan pendekatan filosofis dalam kajiannya adalah sebagai berikut:

a. Agar hikmah, hakikat atau inti dari ajaran agama dapat dimengerti dan dipahami secara seksama.

b. Setiap individu dapat memberi makna terhadap segala sesuatu yang dijumpainya dan mengambil hikmah sehingga ketika melakukan ibadah atau apa pun, ia tidak mengalami degradasi spriritualitas yang menimbulkan kebosanan.

c. Membentuk pribadi yang selalu berpikir kritis (critical thought).

d. Adanya kebebasan intelektual (intellectual freedom).

e. Membentuk pribadi yang selalu toleran.

\section{Pendekatan Historis}

Sejarah atau historis adalah suatu ilmu yang di dalamnya dibahas berbagai peristiwa dengan memperhatikan unsur tempat, waktu, objek, latar belakang dan pelaku dari peristiwa tersebut. 
Melalui pendekatan sejarah seseorang diajak menukik dari alam idealis ke alam yang bersifat empiris dan mendunia. Dari keadaan ini seseorang akan melihat adanya kesenjangan atau keselarasan antara yang terdapat dalam alam idealis dengan yang ada di alam empiris dan historis.

Pendekatan studi Islam melalui sejarah setidaknya ada lima tahapan dalam penelitian. a) Pemilihan topik

b) Pengumpulan sumber; Seperti dokumen tertulis, foto, bangunan, alat dsb.

c) Verifikasi, Pembuktian dalam kritik sejarah, keabsahan sumber, otentisitas dan kredibilitas. d) Interpretasi Analisa dan sintesis

e) Penulisan, Pengantar hasil penelitian dan kesimpulan.

Mengkaji Islam perlu adanya bukti sejarah karena sejarah juga sangat penting untuk di teliti agar kebenaran Islam lebih bisa di perdalam. Dalam hal ini penulis akan memberikan contoh tentang pembangkangan iblis, pada surat Al Baqarah ayat 34:

Artinya : "Dan (ingatlah) ketika Kami berfirman kepada para malaikat: "Sujudlah kamu kepada Adam," maka sujudlah mereka kecuali Iblis; ia enggan dan takabur 
dan adalah ia termasuk golongan orang-orang yang kafir" (QS. Al-Baqarah:34)

Dalam wacana pemikiran Islam kisah ini menimbulkan berbagai kontroversi sekitar dramatisasi pembangkangannya. Ada sebagian pendapat yang menyatakan bahwa sikap pembangkangan iblis ( hal ini tidak sujud kepada Adam ) adalah wujud ketaatan iblis dalam memegang kukuh monoteisme Allah dengan berdasar pernyataan iblis "aku tidak akan menyembah kecuali pada-Mu". Ada juga yang berpendapat bahwa sikap pembangkangan ini merupakan wujud dari keunggulan intektualnya di antara kelompok malaikat lain.

Perbedaan pendapat tersebut dapat kita jadikan pokok permasalahan dalam pengkajian islam. Menurut syekh Mustafa perbedaan persepsi dari kalangan ulama mengenai iblis ini berkisar pada dua hal. Pertama, iblis adalah sejenis jin yang berada diribuan malaikat, berbaur dengan sifat dari sebagian sifat mereka. Kedua iblis itu dari malaikat. Karena perintah sujud di sini tertuju pada malaikat. Iblis itu adalah makna dari kata sujud, fasjudu. Terhadap kata ini baik tafsir klasik maupun modern, sependapat bahwa makna kata sujud yang dimaksud adalah sujud tahiyyat, penghormatan, bukan sujud dalam pengertian ibadah atau menghambakan diri pada 
Adam.

Sebagai sintesis dalam penafsiran dan pemaknaan yang bersifat dualisme tersebut menyangkut masalah Iblis, maka dalam hal ini perlu penelitian yang lebih mendalam bisa dilihat dalam dua aspek. Pertama, dengan memperhatikan fungsi lafaz atau ucapan jin dan malaikat di dalam al-Qur'an dan kedua pada aspek makna etimonologinya. Dari kedua aspek ini tidak dapat dipahami bahwa tidak ada garis dikotomis dan prinsipiil yang membedakan antara malaikat dan jin. Sesungguhnya keduanya hanya berbeda golongan ketika membicarakan sifat sifatnya.

\section{Pendekatan Kebudayaan}

Dalam Kamus Umum Bahasa Indonesia, kebudayaan diartikan sebagai hasil kegiatan dan penciptaan batin (akal budi) manusia seperti kepercayaan, kesenian, adat istiadat; dan berarti pula kegiatan (usaha) batin (akal dan sebagainya) untuk menciptakan sesuatu yang termasuk hasil kebudayaan. Sementara itu, Sutan Takdir Alisjahbana mengatakan bahwa kebudayaan adalah keseluruhan yang kompleks, yang terjadi dari unsur-unsur yang berbeda seperti pengetahuan, kepercayaan, seni, hukum, moral, adat istiadat dan segala kacakapan lain yang diperoleh manusia sebagai anggota masyarakat. 
Dengan demikian, kebudayaan adalah hasil daya cipta manusia dengan menggunakan dan mengarahkan segenap potensi batin yang dimilikinya. Pendekatan kebudayaan adlah pendekatan melalui budaya seperti kepercayaan, kesenian, adat istriadat. Misalnya cara berpakaian di saat resepsi pernikahan, kehidupan sehari-hari, pergaulan antara pria dan wanita dan upacara-upacara keagamaan.

Konsep mengenai kebudayaan yang dikemukakan seperti tersebut diatas itulah yang dapat digunakan sebagai alat atau kacamata untuk mendata dan mengkaji serta memahami agama. Bila agama dilihat dengan menggunakan kacamata agama, maka agama diperlakukan sebagai kebudayaan; yaitu: sebagai sebuah pedoman bagi kehidupan masyarakat yang diyakini kebenarannya oleh para warga masyarakat tersebut. Agama dilihat dan diperlakukan sebagai pengetahuan dan keyakinan yang dipunyai oleh sebuah masyarakat; yaitu, pengetahuan dan keyakinan yang kudus dan sakral yang dapat dibedakan dari pengetahuan dan keyakinan sakral dan yang profan yang menjadi ciri dari kebudayaan. Pada waktu kita melihat dan memperlakukan agama sebagai kebudayaan maka yang kita lihat adalah agama sebagai keyakinan yang hidup yang ada dalam masyarakat manusia, dan bukan agama yang ada dalam teks suci, yaitu dalam kitab suci Al Qur'an 
dan Hadits Nabi. Sebagai sebuah keyakinan yang hidup dalam masyarakat, maka agama menjadi bercorak lokal; yaitu, lokal sesuai dengan kebudayaan dari masyarakat tersebut. Mengapa demikian? untuk dapat menjadi pengetahuan dan keyakinan dari masyarakat yang bersangkutan, maka agama harus melakukan berbagai proses perjuangan dalam meniadakan nilainilai budaya yang bertentangan dengan keyakinan hakiki dari agama tersebut dan untuk itu juga harus dapat mensesuaikan nilai-nilai hakikinya dengan nilainilai budaya serta unsur-unsur kebudayaan yang ada, sehingga agama tersebut dapat menjadi bagian yang tidak terpisahkan dari berbagai unsur dan nilai-nilai budaya dari kebudayaan tersebut. Dengan demikian maka agama akan dapat menjadi nilai-nilai budaya dari kebudayaan tersebut.

Bila agama telah menjadi bagian dari kebudayaan maka agama juga menjadi bagian dari nilai-nilai budaya dari kebudayaan tersebut. Dengan demikian, maka berbagai tindakan yang dilakukan oleh para warga masyarakat untuk pemenuhan kebutuhankebutuhan kehidupan mereka dalam sehari-harinya juga akan berlandaskan pada etos agama yang diyakini. Dengan demikian, nilai-nilai etika dan moral agama akan terserap dan tercermin dalam berbagai pranata yang ada dalam masyarakat tersebut. Sebaliknya, bila yang menjadi inti dan yang hakiki dari 
kebudayaan tersebut adalah nilai-nilai budaya yang lain, maka nilai-nilai etika dan moral dari agama yang dipeluk oleh masyarakat tersebut hanya akan menjadi pemanis mulut saja atau hanya penting untuk upacara-upacara saja.

Apakah gunanya menggunakan pendekatan kebudayaan terhadap agama. Yang terutama adalah kegunaannya sebagai alat metodologi untuk memahami corak keagamaan yang dipunyai oleh sebuah masyarakat dan para warganya. Kegunaan kedua, sebagai hasil lanjutan dari kegunaan utama tersebut, adalah untuk dapat mengarahkan dan menambah keyakinan agama yang dipunyai oleh para warga masyarakat tersebut sesuai dengan ajaran yang benar menurut agama tersebut, tanpa harus menimbulkan pertentangan dengan para warga masyarakat tersebut. Yang ketiga, seringkali sesuatu keyakinan agama yang sama dengan keyakinan yang kita punyai itu dapat berbeda dalam berbagai aspeknya yang lokal. Tetapi, dengan memahami kondisi lokal tersebut maka kita dapat menjadi lebih toleran terhadap aspek-aspek lokal tersebut, karena memahami bahwa bila aspek-aspek lokal dari keyakinan agama masyarakat tersebut dirubah maka akan terjadi perubahan-perubahan dalam berbagai pranata yang ada dalam masyarakat tersebut yang akhirnya akan menghasilkan perubahan kebudayaan 
yang hanya akan merugikan masyarakat tersebut karena tidak sesuai dengan kondisi-kondisi lokal lingkungan hidup masyarakat tersebut.

\section{Pendekatan Psikologis}

Psikologi merupakan ilmu pengetahuan yang mempelajari masalah- masalah kejiwaan manusia yang tercermin dalam perilaku yang nyata. Objek formal psikologi merupakan jiwa manusia. jiwa manusia bersifat abstrak dan tidak konkret, karena itu untuk memenuhi unsur empiris psikologi sebagai ilmu pengerahuan, maka psikologi mempelajari gejalagejala jiwa manusia yang tampak secara lahir.

Layaknya disiplin ilmu yang lain, disiplin ilmu psikologi dapat dipakai untuk mengkaji gejala keberagaman masyarakat, termasuk didalamnya mesyarakat Muslim. Apa yang dikaji oleh studi Islam menggunakan pendekatan psikologi merupakan hubungan Antara agama dengan jiwa manusia. Hubungan ini dikaji melalui gejala jiwa manusia yang lahir dalam tingkah laku dalm hubungannya dengan agama Islam.

Psikologi atau ilmu jiwa adalah jiwa yang mempelajari jiwa seseorang melalui gejala perilaku yang dapat diamatinya. Menurut Zakiah Daradjat, perilaku seseorang yang tampak lahiriah terjadi karena dipengaruhi oleh keyakinan yang dianutnya. Ilmu jiwa 
agama sebagaimana yang dikemukakan Zakiah Daradjat, tidak akan mempersoalkan benar tidaknya suatu agama yang dianut seseorang, melainkan yang dipentingkan adalah bagaimana keyakinan agama tersebut terlihat pengaruhnya dalam perilaku penganutnya.

Dengan ilmu jiwa ini seseorang selain akan mengetahui tingkat keagamaan yang dihayati, dipahami dan diamalkan seseorang juga dapat digunakan sebagai alat untuk memasukkan agama ke dalam jiwa seseorang sesuai dengan tingkatan uasianya. Dengan ilmu agama akan menemukan cara yang tepat dan cocok untuk menanamkannya.

Tidak dapat dipungkiri, bahwa agama sangat memengaruhi jiwa penganutnya. Jiwa tersebut dapat diamati secara empi ris dengan mengamati tingkah-lakunya dengan menggunakan pendekatan psikologis.

Bagian ilmu psikologi yang memfokusk an kajiannya pada jiwa manusia dalam hubungannya dengan agama disebut dengan psikologi agama. Lebih lanjut,psikologi agama dapat dikatakan sebagai hasil dari studi keagamaan yang menggunakan pendekatan psikologis.

Pendekatan psikologis merupakan pendekatan yang bertujuan untuk melihat keadaan jiwa pribadipribadi yang beragama. Dalam pendekatan ini, yang menarik bagi peneliti merupakan keadaan jiwa 
manusia dalam hubungannya dengan agama, baik pengaruh maupun akibat. Lebih lanjut, bahwa pendekatan psikologis bertujuan untuk menjelaskan fen.omena keberagamaan manusia yang dijelaskan dengan mengurai keadaan jiwa manusia.

Pendekatan psikologis sangat bergantung erat dengan teori-teori psikologi umum yang dikembangkan oleh sarjana-sarjana Eropa. Karena itu pendekatan psikologis dalam studi Islam juga menggunakan teori. teori yang sama. Perbedaannya hanya pada beberapa dasarnya dan ruang lingkupnya yang lebih sempit.

Islamisasi psikologi sendiri belum mampu menemukan teori-teori khusus yang bisa digunakan dalam pendekatan terhadap studi keislaman. Akan tetapi hal tersebut bukan hal yang salah ar.au memalukan karena tidak bertentangan dengan ajaran-ajaran Islam.

Pendekatan psikologis bertujuan unruk menjelaskan keadaan jiwa seseorang. Keadaan jiwa rersebut dapat diamati melalui tingkah.laku, sikap, can berpikir dan berbagai gejala jiwa lainnya. Dalam penelitian, informasi tentang gejala-gejala tersebut dapat bersumber dari berbagai hal, seperti observasi. Ada beberapa teknik untuk mendapatkan informasi dari sumber informasi yang digunakan dalam penggunaan pendekatan psikologis, yakni:

a. Studidokumen pribadi (personal document) 
Teknik ini bertujuan untuk menemukan informasi terkait dengan kejiwaan seseorang pada dokumen yang bersifat pribadi, seperti surat, autobiografi, catatan harian atau tulisan lainnya yang merupakan karya dari pribadi yang diteliti.

b. Kuesioner dan Wawancara

Teknik ini bertujuan untuk menemukan informasi terkait dengan pemikiran, konsep atau pengalaman mendalam dari informan agar peneliti dapat mereduksi dan menganalisa berdasarkan data yang didapatkan.

Pendekatan psikologis merupakan pendekatan yang memfokuskan pencarian terhadap masalah kejiwaan manusia. Karena itu, psikologi agama mencari masalah kejiwaan dalam hubungannya dengan agama. Ada beberapa contoh studi Islam yang dapat didekati dengan pendekatan psikologis, antaralain:

a. Tentang masalah perasaan seorang ahli tasawuf yang merasa bahwa Allah selalu dekat dengannya dan hadir dalam hatinya dan ia melakukan dzikir secara terus-menerus dan secara sadar. Masalah pokok dalam kajian ini merupakan perasaan (dekat dengan Allah) manusia (ahli rasawuf) dan bagaimana perasaan tersebut muncul.

b. Masalah lainnya merupakan masalah kepuasan 
seorang hamba terhadap kehidupannya. Di mana bisa dibandingkan antara dua gejala yakni seorang yang sederhana tapi mempunyai tingkat ibadah yang lebih tinggi dengan seorang yang cukup rapi mempunyai tingkat ibadah yang rendah. Masalah pokok yang dicari merupakan pengaruh tingkat ibadah tersebut terhadap rasa puas dalam kehidupan.

\section{Pendekatan Fenomenologis}

Pendekatan fenomenologis dalam agama merupakan suatu pendekacan yang didesain sedemikian rupa yang berakar dari pen dekatan filosofis sebagaimana diakui sendiri oleb Amin Abdullah, bahwa mencermati cara kerja metode fenomenologi, orang sulit menghindari kesan adanya pengaruh pendekacan filsafat terbadap metode pendekatan fenomenologi cukup berjasa dalam membuka wawasan dan cakrawala baru dalam mencari "esensi" keberagamaan manusia."

Dalam kerja penelitiannya, fenomenologi dapat mengacu pada tiga hal, yaitu: filsafat, sejarah, dan pada pengertian yang lebih luas. Dengan demikian "fenomenologi agama" dalam acuan yang pertama menghubungkan dirinya sebagai salah satu disiplin ilmu. Adapun acuan yang kedua memasukkan pendapat tentang sejarah agama. Dengan sendirinya 
mereka mempergunakan religi sederhana sebagai data, dan meletakkan ekspresi keagamaan dalam bentuk simbol seperti bentuk- bentuk upacara keagamaan sebagai fokus perhariannya. Acuan ketiga merupakan penerapan metode fenomenologi secara lebih luas. Metode ini biasa diterapkan dalam menelaah atau meneliti ajaran-ajaran, kegiatan kegiatan, lembaga-lembaga, tradisi-tradisi, dan simbolsimbol keagamaan.

Perkembangan studi agama dengan pendekatan fenomenologis dewasa ini mengalami kemajuan yang sangat signifikan. Terdapat tiga poin siginifikansi fenomenologi dalam studi agama:

a. Mencari bentuk-bentuk dan struktur agamaagama, dan akhirnya dari suatu agama tertentu. Para fenomenolog berusaha untuk mengidentifikasi komponen-komponen utama dalam bahan-bahan, struktur, (yang mungkin tampak sebagai fenomena yang independen atau sebagai hubungan antar fenomena dan fungsi fenomena keagarnaan.

b. Berusaha memahami fenomena keagamaan yang bekerja dalam dua tingkatan, pertama, ia mencoba mencari tempat dari sifat bawaan keagamaan dalam suatu budaya, yaitu apa makna agama bagi orang - orang yang ada di dalam kebudayaan 
tersebut, kedua, ia melibatkan pemahaman umum terhadap elemen - elemen keagamaan dalam hubungan yang lebih luas, yaitu makna teoretisnya.

c. Menyediakan suatu makna bagi sejarah agamaagama dengan cara menerangkannya bersama dan mengintegrasikannya. Fenomenologi agama menawarkan jalan keluar dan dilema yang memberikan sebuah perspektif bersama bagi semua sejarawan agama, dan memberikan suatu kerangka kerja bagi riset baru yang menggusur gaya lama, sejarah agama yang berorientasi-filologi, berupa studi terhadap situasi kegamaan masa kini, akulturasi keagamaan, dan kemunculan bentukbentuk keagarnaan baru. Dengan demikian, hanya dengan bantuan fenomenologi sejarah agamaagama dapat menjadi sebuah disiplin yang mampu menjangkau semua agama.

Meskipun pendekaran fenomenologi agama cenderung muncul belakangan dibandingkan dengan pendekatan-pendekatan yang lain, seperti sosiologi agama, antropologi agama, psikologi agama, sejarah agama, dan lain-lain, akan tetapi ia memainkan peranan yang sangat penting dalarn hal mengungkap makna perilaku keberagaman manusia dan substansi dari agama-agama itu sendiri. 


\section{Pendekatan Komparatif}

Adapun pendekatan atau metode komparatif secara bebas diartikan sebagai pengoordinasian seluruh data yang sebanding secara tidak rnemihak dan tanpa prasangka, terlepas dari konteks atau masa. Dalamstudi agama komparativisme itu sendiri dapat digolongkan sebagai upaya penting dan repat sebagai sebuah lapangan penyelidikan dan bagian inti dari proses pembentukan, pengujian dan penerapan generalisasi tenrang agama pada tingkat mana pun.

Beberapa kata atau istilah yang dipakai untuk Tujuan perban dingan, sekaligus keinginan melihat sesutru melalui dua atau lebih dari sasaran persamaan atau perbedaan, anrara lain komparatif, sama atau persamaan, beda atau perbedaan, kemudian komparatif persamaan atau perbandingan.

Bila ditinjau dari segi unsur-unsur yang terdapat dalam komparatif serta tujuan dan makna yang terkandung di dalamnya, dapat diasumsikan bahwa praktik metode komparatif tersebut selalu muncul di kalangan intelektual baik dalam hal, bentuk dan sifatnya. Asumsi ini dilan dasi atas dasardasar berpikir sebagai berikut: 
a. Adanya keraguan untuk membuka peluang untuk adanya perbandingan antata saru dengan yang lain.

b. Kalangan intelektual merupakan orang-orang yang selalu membutuhkan keragamankeragaman, pendapat, argumentasi prinsip keyakinan, mazhab, agama dan lainnya.

Untuk melihat lebih lanjut adanya unsur komparatif dalam rradisi pengkajian Islam, dapat ditinjau dari:

a. Adanya pengertian atau definisi yang berbeda dalam berbagai masalah dalam suatu ilmu.

b. Adanya banyak pendapat dalam berbagai disiplin ilmu.

c. Adanya mazhab-mazhab dalam kajian ilmu .

d. Adanya berbagai keyakinan dan agarna.

e. Adanya berbagai macam keahlian dan orang-orang yang ahli.

Pendekatan komparatif ini bisa digunakan dengan bantuan pendekatan sejarah, seperti dalam menguraikan perbandingan Antara mazhab-mazhab hukum, politik dan teologi. Pendekatan komparatif dengan menggunakan bantuan atau dengan kom 
binasi pendekatan sejarah merupakan corak yang paling sering muncul dalam mengkaji perbandingan objek-objek yang berbau klasik.

\section{Pendekatan Interdisipliner}

Dalam kamus bahasa Indonesia Interdisipliner berarti bidang studi atau pengelompokan sejumlah mata pelajaran yang sejenis atau memiliki ciri yang sama (mata pelajaran yang telah berkorelasi satu dengan yang lain). Bahwa Interdisipliner merupakan disiplin ilmu antara ilmu yang satu dengan yang lainnya saling berkaitan atau memiliki hubungan. Pendekatan Interdisipliner merupakan pemahaman ilmu "agama islam" dengan menggunakan beberapa keilmuan yang saling berkaitan. Dalam mengkaji islam dengan studi interdisipliner haruslah dengan beberapa ilmu yang serumpun atau ilmu yang saling berkaitan.

Pendekatan interdisipliner yang dimaksud di sini adalah kajian dengan menggunakan sejumlah pendekatan atau sudut pandang (perspektif). Dalam studi misalnya menggunakan pendekatan sosiologis, historis dan normatif secara bersamaan. Pentingnya penggunaan pendekatan ini semakin disadari keterbatasan dari hasil-hasil penelitian yang hanya 
menggunakan satu pendekatan tertentu. Misalnya, dalam mengkaji teks agama, seperti Al-Qur'an dan sunah Nabi tidak cukup hanya mengandalkan pendekatan tekstual, tetapi harus dilengkapi dengan pendekatan sosiologis dan historis sekaligus, bahkan masih perlu ditambah dengan pendekatan hermeneutik misalnya.

Dari kupasan di atas melahirkan beberapa catatan. Pertama, perkembangan pembidangan studi Islam dan pendekatannya sejalan dengan perkembangan ilmu pengetahuan itu sendiri. Kedua, adanya penekanan terhadap bidang dan pendekatan tertentu dimaksudkan agar mampu memahami ajaran Islam lebih lengkap (komprehensif) sesuai dengan kebutuhan tuntutan yang semakin lengkap dan detail. Ketiga, perkembangan tersebut adalah satu hal yang wajar dan seharusnya memang terjadi, kalau tidak menjadi pertanda agama semakin tidak mendapat perhatian.

Studi Islam Interdisipliner merupakan pengembangan dan penjabaran dari tiga topik yaitu pendekatan filsafat, sosiologi dan sejarah yang penekanannya lebih diarahkan pada aspek aplikasinya.

Dari uraian di atas pendekatan interdisipliner merupakan pendekatan yang menggunakan beberapa ilmu yang relevan antara satu ilmu kajian dengan 
kajian yang lain itu penerapanya serumpun. Dalam pembahasan ini penulis akan membahas tentang pendekatan filsafat, sosiologi dan sejarah. Karena tiga ilmu ini saling terkait dan saling berhubungan ketika dalam mengkaji teks / Nash - Nash dalam al-Qur'an maupun al-Hadist.

\section{RANGKUMAN}

1. Pendekatan normatif adalah studi Islam yang memandang masalah dari sudut legal formal dan atau normatifnya. Maksud legal formal adalah hubungannya dengan halal-haram, boleh atau tidak,dan sejenisnya. Sementara normatifnya adalah seluruh ajaran yang terkandung dalam nash.

2. Pendekatan antropologi budaya dan sosial dapat digunakan dalam upaya mengkaji fenomenafenomena keagamaan tersebut dengan tujuan untuk lebih dapat memahami perilaku umat Islam dan dalam rangka pembangunan kehidupan beragama umat Islam itu sendiri.

3. Fokus pada pendekatan sosiologi dalam studi Islam adalah memahami Islam sebagai fenomena yang menyejarah dalam sosial dan budaya.

4. Filsafat dalam segala usahanya untuk mengetahui berbagai hakikat dari segala sesuatu, begitu pula ketika ia dipakai dalam mengkaji Islam, tidak selalu 
mencapai hasil yang maksimal, yang terpenting adalah upaya (memanfaatkan hasil usaha), yang akan membuat suatu perubahan ke arah yang lebih baik lagi atau kemajuan.

5. Pendekatan sejarah merupakan pendekatan yang akan melihat adanya kesenjangan atau keselarasan antara yang terdapat dalam alam idealis dengan yang ada di alam empiris dan historis.

6. Pendekatan kebudayaan adlah pendekatan melalui budaya seperti kepercayaan, kesenian, adat istriadat.

7. Pendekatan psikologis merupakan pendekatan yang bertujuan untuk melihat keadaan jiwa pribadi-pribadi yang beragama.

8. Pendekatan fenomenologi agama memainkan peranan yang sangat penting dalarn hal mengungkap makna perilaku keberagaman manusia dan substansi dari agama-agama itu sendiri.

9. Pendekatan komparatif diartikan sebagai pengoordinasian seluruh data yang sebanding secara tidak memihak dan tanpa prasangka, terlepas dari konteks atau masa.

10. Pendekatan interdisipliner yang dimaksud di sini adalah kajian dengan menggunakan sejumlah pendekatan atau sudut pandang (perspektif).

D. LATIHAN 
Analisislah bersama kelompokmu, sebuah kajian keislaman dengan menggunakan salah satu pendekatan studi Islam yang sesuai! 


\section{BAB V}

\section{KAJIAN ISLAM KONTEMPORER PERSPEKTIF INSIDER/OUTSIDER}

\section{A. PENDAHULUAN}

Kajian tentang Islam (Islamic Studies/Dirasah Islamiyyah) dewasa ini begitu diminati oleh berbagai pihak. Bukan hanya para cendekiawan muslim saja yang serius mengkaji Islam, akan tetapi juga orang-orang Barat non-Muslim juga menggeluti Islam sebagai obyek kajian. Namun demikian, bukan hanya kaum orientalis yang mengkaji Islam secara analisis, para cendekiawan pun tertarik dengan berbagai kajian Islam yang menyuguhkan berbagai disiplin keilmuan.

Dalam sejarahnya, kelimuan Islam telah berproses sedemikian rupa hingga memunculkan berbagai disiplin keilmuan yang mana dikaji dari berbagai pendekatan. Perkembangan keilmuan Islam telah diwarnai dengan berbagai realitas yang dengan jelas berpengaruh atau dipengaruhi oleh perubahan zaman menuju modernitas.

Kemunculan kajian atau studi tentang keislaman kontemporer adalah akibat dari sentuhan tradisionalitas dan modernitas yang berasal dari Barat. Persinggungan keduanya itu terjadi karena pembelaan terhadap pendapat-pendapat tradisional akan tetapi juga nalar kritis yang mengkritisi tradisionalitas itu sendiri.

Lebih dari itu, Islam adalah sebuah agama yang mana menjadi sebuah agama yang kaya akan ilmu 
pengetahuan dilihat dari berbagai pendekatan. Berangkat dari sebuah keyakinan yang mendasarkan Al-Qur'an dan Hadits Nabi Muhammad Saw. Dari kedua sumber hukum tersebut muncullah berbagai tafsir (interpretation) yang mana kemudian lahirlah berbagai kajian dan pembahasan secara

ilmiah.

Dengan demikian, Islam kemudian menjadi suatu obyek kajian dan pembahasan yang bisa disoroti dari berbagai pendekatan dan sudut pandang. Dalam hal ini, Fazlur Rahman pun menanggapi dan merumuskan bahwa Islam itu terbagi menjadi Islam normatif dan Islam historis dilihat dari pembumiannya terhadap pandangan sosiokultural.

Begitu luas studi atau kajian tentang Islam di era kini. Sekarang ini, kebutuhan terhadap kajian Islam kontemporer tidak bisa dan tidak boleh diabaikan. Minat dan antusiasme kalangan akademisi terhadap bidang pemikiran tersebut pun sangat besar. Hal itu dapat dilihat dari produksi karya ilmiah yang menggunakan metode kontemporer dalam mengkaji Islam.

Melalui pembahasan ini mahasiswa diharapkan mampu memahami hasil dari kajian keislaman para insider maupun outsider sebagai referensi ilmu yang berkenaan dengan permasalahan Islam. 


\section{B. PENYAJIAN}

\section{Richard C. Martin}

\section{a. Biodata Richard C. Martin}

Richard C. Martin adalah profesor agama di Emory University. la menjabat sebagai Ketua Departemen Agama pada tahun 1996-1999. Bidang-bidang keahliannya meliputi studi Islam (Islamic Studies), studi perbandingan agama serta agama dan konflik.

Dia menjabat di beberapa dewan akademis nasional dan komite, seperti Komite Eksekutif Pusat Penelitian Amerika di Mesir. Ia telah memberi kuliah secara luas di Amerika Serikat, Eropa, Afrika Selatan dan Asia Tenggara pada topik- topik yang terkait dengan Islam dan sejarah agama. Profesor Martin pernah tinggal dan melakukan penelitian di Mesir dan di tempat-tempat lain di dunia Muslim. Dia juga terlibat dalam proyek kerjasama dengan ulama Muslim.

\section{b. Kritik Pemikiran Richard C. Martin dalam Studi Islam}

Richard C. Martin mengemukakan ingin membuka kemungkinan kontak dan pertemuan langsung antara tradisi berpikir keilmuan dalam Islamic Studies secara tradisional dan tradisi berpikir keilmuan dalam Religious Studies kontemporer yang telah memanfaatkan kerangka 
teori, metodologi dan pendekatan yang digunakan oleh ilmu-ilmu sosial dan humaniora yang berkembang sekitar abad ke 18 dan 19.

Buku suntingan Richard C. Martin yang berjudul Approaches to Islam in Religious Studies sarat dengan muatan metodologi. Upayanya diarahkan untuk membawa dan mengangkat Islamic Studies keluar dari jebakan historis-kulturalnya sendiri ke wilayah arus besar pusaran ilmu agama (Religionwissenschaft) yang berkembang sejak abad ke-19 dengan berbagai perangkat metodologi yang dimilikinya. Upaya ini diharapkan dapat menjembatani kesenjangan metodologis antara Islamic Studies dan Religionwissenschaft.

Richard C. Martin di awal bab menjelaskan tentang Islam dan posisinya dalam studi agama. Dikatakan olehnya bahwa pemahaman tentang Islam sebagai agama dan pemahaman tentang agama dari sudut pandang Islam merupakan persoalan yang perlu dielaborasi dalam diskusi dan pembahasan para sarjana di bidang studi agama.

Sebagai editor, Martin menjelaskan bahwa bidang-bidang data (data fields) yang dikaji dalam buku suntingannya adalah bidang-bidang data tentang Islam yang menebar luas secara historis dan geografis. Sedang jenis-jenisnya terbentang dari jenis-jenis tekstual, sosial-historis, hingga ritual- 
simbolis. Buku ini bermaksud mempresentasikan kritisisme konstruktif dari pendekatan-pendekatan yang sudah lama diterima terhadap studi Islam dan bermaksud untuk menerapkan metode-metode dan teori-teori dari disiplin-disiplin lain terhadap data keagamaan Islam. Maksudnya adalah untuk memberikan servis tentang perubahan dan pengembangan yang diperlukan dalam studi Islam.

Martin menggunakan kata kunci data fields sebagai basis fokus kajiannya. Data fields yang dikaji adalah bidang-bidang data tentang Islam yang menebar luas secara historis dan geografis. Sedang jenis-jenisnya terbentang dari jenis-jenis tekstual, sosial-historis, hingga ritual-simbolis. Martin bermaksud mempresentasikan kritisisme konstruktif terhadap studi Islam dan bermaksud untuk menerapkan perangkat ilmiah disiplin disiplin lain terhadap data keagamaan Islam. Maksudnya adalah untuk memberikan servis tentang perubahan dan pengembangan yang diperlukan dalam studi Islam sebagai agama.

Richard C. Martin dalam tulisannya yang berjudul Approaches to Islam in Religious Studies merasa bahwa Islam harus mendapatkan perhatian yang lebih dalam studi agama saat ini dikarenakan pengaruh global dan pertumbuhan penduduk muslim dunia. Dari berbagai pendekatan dalam studi Islam, 
Richard C. Martin lebih menekankan pada pendekatan kesejarahan. Sehingga kajian-kajian yang menggunakan pendekatan klasik sepertinya tidak bisa lagi dianggap sebagai kajian komprehensif lagi. Martin mengusulkan metodologi yang merupakan perpaduan antara metode-metode dalam Islamic Studies Konvensional dengan karakter deskriptif historis, filologis dan sastrawi dengan metode humanities studies kontemporer seperti hermeneutika, fenomenologi, sosiologi dan antropologi. Temuan dari metode konvensional tetap akan menjadi bahan untuk srudi lebih lanjut dengan menggunakan metode kontemporer humanities studies.

\section{Omid Safi}

\section{a. Biografi Omid Safi}

Omid Safi adalah pemikir Muslim berkebangsaan Amerika Serikat berdarah Iran. Oleh karena itu, pemikirannya sepertinya dipengaruhi motivasinya untuk mempertemukan Islam dengan "kesalahpahaman" Barat, dalam hal ini Amerika. Sudah menjadi maklum bahwa Islam oleh Barat selalu dikonotasikan sebagai agama yang keras, kaku, tidak menghargai hak perempuan, tidak mengedepankan hak azazi manusia, dan fanatik. Omid Safi ingin menyadarkan Barat bahwa Islam sangat ramah lingkungan, sangat menjunjung hak 
asasi manusia, menghormati perempuan, dan mentoleransi pluralisme. Oleh karena itu, Islam harus ditampilkan dengan wajah yang demokratis, adaptif, pluralis, dan progresif.

Karir akademisnya dimulai dari North Carolina University sebagai alamamater utamanya. Di sini ia meraih posisi asisten professor, sebelum akhirnya pada tahun 2010 dianugerahi gelar sebagai guru besar penuh (professor) pada kajian studi keislamam klasik dan kontemporer. Selain di perguruan tinggi tersebut, Omid Safi meraih penghargaan sebagai pengajar dan dosen tamu favorit dari beberapa perguruan tinggi lain di Amerika, seperti Colgate University, Duke University, dan Harvard University. Di Harvard, ia membidani lahirnya kajian pluralism dan memimpin Islamic Studies: American Academy of Religion. Di luar kampus, Omid Safi juga memimpin perkumpulan sufi (misticism) bagi Muslim Amerika.

\section{b. Studi Analisis Gender Mainstreaming Omid Safi dalam Agenda Muslim Progresif}

Metode yang digunakan Omid Safi dalam merumuskan konsepnya tentang Muslim Progressive adalah metode multiple critique. Dalam makna yang sangat sederhana multple critique ini dapat diartikan sebagai kritik ganda, di mana kita sebagai umat 
muslim harus mampu mengkritisi diri sendiri di satu sisi dan juga harus mampu mengkritisi Barat dalam sisi yang lain. Kritik ganda juga berbasis penggunaan pendekatan beragam arah (a multi-headed approach based) yang didasarkan pada kritik simultan terhadap beragam komunitas dan wacana di mana kita terlibat langsung di dalamnya.

Omid Safi mengatakan bahwa setiap manusia yang lahir tanpa dibedakan Muslim-non Muslim, laki-laki perempuan, ras apa pun, warna kulit apa pun, suku apa pun, dan seterusnya, memiliki nilai yang sama, yaitu sama-sama dibekali dengan nilai kesucian ruh Tuhan. Oleh karena itu, semua manusia berhak mendapatkan perlakuan yang sama, keadilan, kesetaraan, dan kesempatan yang sama tanpa harus dibedakan jenis agama, kelamin, suku bangsa, ras, dan lain sebaginya. Dengan ini pula, segala bentuk ketidakadilan, diskriminasi, penjajahan, perbudakan, dan segala ketimpangan kemanusian harus dikritisi dan diperbaiki. Dalam kesempatan lain, Safi mengatakan bahwa justru sering dijumpai adanya perlakuan tidak adil, diskriminatif, otoriter, dan tidak demokratis yang justru dilakukan umat Muslim dan justru mengatasnamakan Islam.

\section{Fethulah Gulen}




\section{a. Biodata Fethulah Gulen}

Muhammad Fethullah Gülen merupakan sosok ulama yang dalam dekade terakhir ini memberikan pengaruh luas bagi dunia internasional. Mengedepankan pendidikan, dialog, dan toleransi dalam setiap pengajaran yang diberikan kepada para pengikutnya sehingga pergerakan Gülen (belakangan disebut pergerakan hizmet) mengikuti hal tersebut sebagai acuan pergerakan. Gülen seorang inspirator pergerakan sosial baru yang "kontroversial". Pengaruhnya yang kian menguat, khususnya di Turki, menimbulkan berbagai anggapan miring bahwa ia dan pengikutnya merencanakan kudeta atas pemerintahan sekuler yang ada di Turki. la juga dituduh sebagai seorang fundamentalis yang menginginkan berdirinya negara Islam.

\section{b. Pemikiran Pendidikan Islam perspektif Fethulah Gulen}

Pendidikan dalam pandangan yang sebenarnya adalah suatu sistem pendidikan yang memungkinkan seseorang dapat mengarahkan kehidupannya sesuai dengan cita-cita Islam, sehingga dengan mudah ia dapat membentuk hidupnya sesuai dengan ajaran Islam. Pengertian itu mengacu pada perkembangan kehidupan manusia 
masa depan tanpa menghilangkan prinsip-prinsip Islami yang diamanahkan oleh Allah kepada manusia, sehingga manusia mampu memenuhi kebutuhan dan tuntutan hidupnya seiring dengan perkembangan IPTEK. Menurut Gulen:

"Education is perfecting process though which we earn, in the spiritual, intellectual, and physical dimensions of their beings, the rank appointed for us the perfect pattern of creation. Education through learning and a commendable way of life is a sublime duty that manifests the Divine Name Rabb (Upbringer and Sustainer). By fulfilling it, we attain the rank of true humanity and become a beneficial element of society."

Fethullah Gulen menyatakan bahwa kewajiban manusia adalah memahami (Seek Understanding), dengan jalan dan cara apapun. Gulen mendefinisikan pendidikan sebagai proses penyempurnaan dalam hidup yang dengannya kita bisa meraih dimensi spiritual, intelektual dan fisikal kemanusiaan. Baginya, pendidikan adalah tugas llahiyah yang hanya dengan itulah kita bias merasakan esensi kemanusiaan. Pendidikan dalam perspektif Gulen adalah "Special Service" yang menjadi tugas kolektif berbasis komunitas. Hal ini disebabkan pandangannya bahwa tujuan hidup 
terletak pada kebaikan (baca: berbuat baik) yang dilakukan secara bersama-sama. Pandangan Gulen tentang pendidikan dengan demikian tersimpul dan terkait erat dengan sisi keimanannya (fullyintegrated with his belief).

Suatu kali, Gulen pernah berujar "we are only truly human if we learn, teach and inspire others". Kita menjadi manusia hanya karena kita belajar, mendidik dan menginspirasi orang lain. Esensi kemanusian kita dengan demikian bukanlah akal, otak ataupun pikiran, tetapi penggunaan akal agar berguna dan bermanfaat buat orang lain. Pendidikan berbanding lurus dan sederajat dengan kemanusiaan kita. Gulen sering membandingkan manusia dengan hewan dalam soal pendidikan. Hewan hanya dalam hitungan hari bisa mendapatkan kemampuan untuk digunakan seumur hidupnya. Sementara manusia memerlukan puluhan tahun untuk menjadi manusia yang sesungguhnya dan mengenal Tuhannya. Bahkan ada manusia yang hingga akhir hayatnya belum mendapatkan bekal kehidupannya. Soal integrasi pandangannya tentang pendidikan dengan keimanan, ini bisa dibuktikan, misalnya dengan kukuhnya pendirian Gulen tentang mustahilnya ketidak sesuain ilmu pengetahuan modern (Science) dengan ajaran agama (Religious 
Knowledge).

Pendidikan, agama dan sains menjadi prinsip utama pergerakan hizmet sehingga tidak bertentangan dengan prinsip pergerakan civil society lainnya yang mengembangkan keilmuan Islam dengan pendidikan sains, seperti NU dan Muhammadiyah di Indonesia. Meskipun pergerakan hizmet memiliki perbedaan dengan pergerakan NU dan Muhammadiyah, tapi perbedaan ini tidak menyinggung satu dengan yang lain. Ini didasarkan pada pendekatan sufisme yang diajarkan Gülen pada pengikutnya. Melihat konsep dan metode pergerakan hizmet, maka pergerakan ini merupakan implementasi dari pemikiran Gulen tentang integrasi ilmu pengetahuan (sains) dan agama yang sangat toleran, bahkan pemikiran pendidikan Islam Gulen ini telah banyak mempengaruhi pemikiranpemikiran pemuda muslim untuk lebih maju dengan sainsnya tanpa melupakan kehidupan spiritualnya.

\section{Charles J. Adams}

\section{a. Biografi Charles J. Adams}

Charles Joseph Adams lahir pada tanggal 24 April 1924 di Houston, Texas. Pendidikan dasarnya diperoleh melalui sistem sekolah umum. Pada permulaan belajar di sekolah dasar ini Adams telah 
menunjukkan kegemaran menulis. Setelah lulus dari Sekolah Menangah Atas John H. Reagen pada tahun 1941, dia meneruskan di Baylor University di Waco, Texas. Adams juga pernah bergabung dengan Angkatan Udara Amerika Serikat dari tahun 1942 sampai dengan 1945 sebagai operator radio dan mekanis. Setelah perang, tahun 1947 Adams memperoleh gelar Sarjana dan pada tahun yang sama memasuki Graduate School di Universitas Chicago bersama dengan Joachim Wach. Karir akademisi Adams adalah profesor dalam bidang Islamic Studies dan pada tahun 1963 diangkat menjadi director Institute of Islamic Studies McGill University selama 20 tahun. Adams menerima Ph. D dalam History of Religion dari University of Chicago pada tahun 1955 dengan disertasi berjudul "Nathan Soderblom as an Historian of Religions".

\section{b. Pendekatan Studi Islam Charles J. Adams}

Kajian yang mendalam tentang metodologi Studi Islam juga dilakukan oleh Charles J.Adams. Dalam penelitiannya, guru besar Islamic Studies di McGill University itu memulai dengan pertanyaan "What is Islam?" Akhirnya untuk memperluas pengetahuan dan pemahaman tentang islam, Charles J.Adams menawarkan metodologi studi Islam dengan 
pendekatan normatif dan pendekatan Deskriptif. Pendekatan normatif merupakan pendekatan studi agama yang dijiwai motivasi dan tujuan keagamaan sehingga diorientasikan untuk mengajak orang lain agar mengakui apa yang menjadi keyakinannya. Pendekatan ini dapat dikelompokkan menjadi tiga hal; Pendekatan missionaris tradisional, pendekatan apologetik, dan pendekatan irenic. Sedangkan Pendekatan Deskriptif merupakan pendekatan yang ditujuakn untuk memberikan gambaran objektif mengenai Islam sebagai agama. Pendekatan Deskriptif dapat dilakukan dengan tiga hal; pendekatan filologi dan sejarah, pendekatan ilmu - ilmu sosial, dan pendekatan fenomenologi.

\section{RANGKUMAN}

1. Dari berbagai pendekatan dalam studi Islam, Richard Martin lebih menekankan pada pendekatan kesejarahan.

2. Metode yang digunakan Omid Safi dalam merumuskan konsepnya tentang Muslim Progressive adalah metode multiple critique. Dalam makna yang sangat sederhana multple critique ini dapat diartikan sebagai kritik ganda, di mana kita sebagai umat muslim harus mampu mengkritisi diri sendiri di satu 
sisi dan juga harus mampu mengkritisi Barat dalam sisi yang lain.

3. Untuk memperluas pengetahuan dan pemahaman tentang islam, Charles J.Adams menawarkan metodologi studi Islam dengan pendekatan normatif dan pendekatan Deskriptif.

\section{LATIHAN}

Deskripsikan pemikiran dan pendekatam studi Islam Kontemporer dari insider/outsider yang kamu ketahui selain para pemikir yang telah diuraikan diatas! 


\section{DAFTAR PUSTAKA}

Abd. Hakim, Atang, Drs., MA., dkk, Metodologi Studi Islam, Bandung: PT Remaja Rosdakarya Offset. 2008.

Abdullah, Amin, dkk. Studi Agama: Normativitas atau Historisitas?. Yogyakarta: Pustaka Pelajar, 2002.

Abdullah, Amin, dkk. Tafsir Baru Studi Islam dalam Era Multikultural. Yogyakarta: IAIN Sunan Kalijaga, 2002.

Abdullah, Amin, dkk. Mencari Islam; Studi Islam dengan Berbagai Pendekatan. Yogyakarta: Tiara Wacana, 2000.

Anshori, Endang Saifuddin. Ilmu, Filsafat Dan Agama. Surabaya: Bina Ilmu, 1987.

Bakhtiar, Amsal. Filsafat Agama. Jakarta: Rajawali Pers, 2009.

Choir Tholhatul. Islam dalam Berbagai Pembacaan Kontemporer. Pustaka Pelajar, 2009.

Davamony, Mariasusai. Fenomenologi

Agama.

Yogyakarta: Kanisius, 2001. 
Gülen, M. Fethullah. Essay-Perspective-Opinions. Clifton: Tughra Books, 2010.

Hakim M. Nur. Metode Studi Islam. Malang: Universitas Muhammadiyah Malang, 2004.

Kertanegara, Mulyadhi. Menyibak Tabir Kejahilan, Pengantar Epistemologi Islam. Bandung: Mizan, cet. I, 2003.

Khoiriyah. Memahami Metodologi Studi Islam (Suatu Konsep tentang Seluk Beluk Pemahaman Ajaran Islam Studi Islam dan Isu-isu Kontemporer dalam Studi Islam). Yogyakarta: Teras, 2013.

Madjid, Nurcholis. Islam Doktrin \& Peradaban, Bandung: Remgia

Nafis, Muhammad Mustahibun. IImu Pendidikan Islam. Yogyakarta: Teras,

Naim, Ngainun. Pengantar Studi Islam. Yogyakarta: Teras, 2009.

Nasution, Harun. Islam Rasional. Bandung: Mizan, 1996.

Nasution, Khoiruddin, Dr., MA., Pengantar Studi Islam, Yogyakarta: ACAdeMIA + TAZZAFA. 2004.

Nata, Abuddin, Metodologi Studi Islam, Jakarta: PT Raja 
Grafindo Persada. 2006.

Nata, Abuddin. Metodologi Studi Islam. Jakarta: Rajawali Press, 2011.

Safi, Omid. "Introduction: The Time They Are A Changing- A Muslim Quest for Justice, Gender Equality, and Pluralism", dalam Muslim Progressive on Justice, Gender and Pluralism. Ed. Omid Safi. Oxford: Oneworld, 2003.

Sahordi, Jamali. Metodologi Studi Islam. Bandung: Pustaka Setia, 2011.

Santoso. Jakarta: PT. Raja Grafindo Persada, 2002.

Save. M. Dagun, Kamus Besar Ilmu Pengetahuan. Jakarta: Lembaga Pengkajian Kebudayaan Nusantara (LPKN), 1997.

Suriasumantri, Jujun S. Filsafat IImu Sebuah Pengantar Populer, Jakarta: Pustaka Sinar Harapan, 2013.

Tantowi, Ahmad. Pendidikan Islam di Era Transformasi Global. Semarang : Pustakan Rizki Putra, 2008.

terj. Sugeng Hariyanto. Jakarta: PT. Raja Grafindo Persada, 2002. 


\section{BIODATA PENULIS}

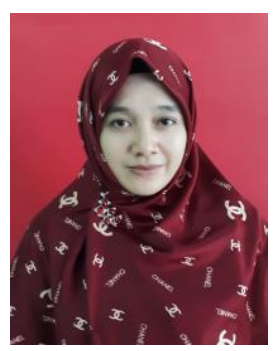

Anita Puji Astutik, lahir di Sidoarjo pada tanggal 21 Januari 1980. Dosen tetap Universitas Muhammadiyah Sidoarjo yang mengampu mata kuliah Al-Islam dan Kemuhamadiyahan dan mata kuliah Pendidikan Agama Islam ini memperoleh gelar kesarjanaan dari Fakultas Tarbiyah jurusan Pendidikan Agama Islam Institut Agama Islam Negeri Sunan Ampel Surabaya dengan predikat Cumlaude (2001). Aktifitas sosial keagamaan di organisasi Aisiyah dan partisipasi di tengah masyarakat serta menjadi praktisi di dunia pendidikan tidak melupakan dahaganya dengan dunia akademis, dengan melanjutkan ke jenjang Pasca Sarjana Universitas Muhammadiyah Sidoarjo. Gelar M.PDI dari Universitas Muhammadiyah Sidoarjo diperoleh dengan predikat Cumlaude pada tahun 2013. Aktivitas menulis terus dilakukan untuk mencegah kebuntuhan idealismenya. Selain menghasilkan karya tulis diberbagai media, juga berkontribusi sebagai penulis buku ajar. Diantara buku hasil karya yang sukses diterbitkan antara lain Islam dan IImu pengetahuan bidang kesehatan, Tahun 2016, dan buku Islam dan IImu Pengetahuan bidang IImu Sosial dan Ilmu Politik, tahun 2017. Kehausannya akan keilmuan 
tentang Islam mengantarkannya kembali ke bangku perkuliahan Konsentrasi kajian Islam Kontemporer diambilnya dalam studi S3 di Universitas Islam Negeri Sunan Ampel Surabaya. 
